\title{
Financial Regulation in a Quantitative Model of the Modern Banking System
}

\section{Citation}

Begenau, Juliane, and Tim Landvoigt. "Financial Regulation in a Quantitative Model of the Modern Banking System." Harvard Business School Working Paper, No. 16-140, June 2016.

(Revised July 2016.)

\section{Permanent link}

http://nrs.harvard.edu/urn-3:HUL.InstRepos:27885353

\section{Terms of Use}

This article was downloaded from Harvard University's DASH repository, and is made available under the terms and conditions applicable to Open Access Policy Articles, as set forth at http:// nrs.harvard.edu/urn-3:HUL.InstRepos:dash.current.terms-of-use\#OAP

\section{Share Your Story}

The Harvard community has made this article openly available.

Please share how this access benefits you. Submit a story.

Accessibility 


\section{Financial Regulation in a Quantitative Model of the Modern Banking System}

Juliane Begenau

Tim Landvoigt

Working Paper 16-140 


\title{
Financial Regulation in a Quantitative Model of the Modern Banking System
}

\author{
Juliane Begenau \\ Harvard Business School \\ Tim Landvoigt \\ University of Texas at Austin
}

Working Paper 16-140 


\title{
Financial Regulation in a Quantitative Model of the Modern Banking System*
}

\author{
Juliane Begenau \\ Harvard University \& NBER
}

\author{
Tim Landvoigt \\ University of Texas at Austin
}

June 2016

\begin{abstract}
How does the shadow banking system respond to changes in the capital regulation of commercial banks? This paper builds a quantitative general equilibrium model with commercial banks and shadow banks to study the unintended consequences of capital requirements. A key feature of our model are defaultable bank liabilities that provide liquidity services to households. The quality of the liquidity services provided by bank liabilities depends on their safety in case of default. Commercial bank debt is fully insured and thus provides full liquidity. However, commercial banks do not internalize the social costs of higher leverage in the form of greater bankruptcy losses (moral hazard), and are subject to a regulatory capital requirement. In contrast, shadow bank liabilities are subject to runs and credit risk and thus typically less liquid compared to commercial banks. Shadow banks endogenously limit their leverage as they internalize its costs. Tightening the commercial banks' capital requirement from the status quo leads to safer commercial banks and more shadow banking activity in the economy. While the safety of the financial system increases, it provides less liquidity. Calibrating the model to data from the Financial Accounts of the U.S., the optimal capital requirement is around $15 \%$.
\end{abstract}

\footnotetext{
*First draft: December 2015. Email addresses: jbegenau@hbs.edu, tim.landvoigt@mccombs.utexas.edu. We would like to thank our discussants Christian Opp, Goncalo Gino, David Chapman, and Hendrik Hakenes, as well as seminar participants at the ASSA 2016 meetings, CITE 2015 conference on New Quantitative Models of Financial Markets, Federal Reserve Bank of Boston, Kellogg, MFM Winter 2016 meeting, NYU Junior Macro-Finance 2016 Meeting, SAFE 2016 Conference on Regulating Financial Markets, SFI Lausanne, Stanford Junior Faculty Workshop on Financial Regulation and Banking, Texas Finance Festival, University of Texas at Austin, WFA 2016, and SED Toulouse 2016.
} 


\section{Introduction}

The regulation of a complex system such as the financial sector may have unintended consequences that can jeopardize the goals of regulatory policies. If regulated financial firms are competing with unregulated financial firms that provide similar services or products, then tighter regulation can cause a shift to the unregulated sector and thus potentially cause more financial instability. For example, Regulation Q - a cap on deposit rates - was introduced after the Great Depression to curb excessive competition for deposit funds that were thought to have weakened the banking system. As long as interest rates remained low, savers had little incentives to pull their funds out of the traditional banking system. But as soon interest rates rose, depositors looked for alternatives and the competition for their savings generated one: money market mutual funds (Adrian and Ashcraft (2012)). This and numerous other examples $^{1}$ highlight the side-effects of regulatory policies that can influence shadow banks' behavior. $^{2}$

In this paper, we study and quantify the effects of capital requirements in a general equilibrium model that features regulated (commercial) and unregulated (shadow) banks. Tightening the capital requirement on commercial banks can shift activity to shadow banks, and thereby potentially increase the fragility of the entire financial system. Calibrating the model to aggregate data from the Flow of Funds, we find that higher capital requirements indeed shift activity away from traditional banks, potentially increasing shadow bank fragility

\footnotetext{
${ }^{1}$ Asset-backed commercial paper conduits are another example for entities that emerged arguably as a response to regulation, more precisely capital regulation (see Acharya, Schnabl, and Suarez (2013)).

${ }^{2}$ We define shadow banks as financial institutions that share features of depository institutions, either by providing liquidity services such as money market mutual funds or by providing credit either directly (e.g. finance companies) or indirectly (e.g. security-broker and dealers). At the same time, they are not subject to the same regulatory supervision as traditional banks. Importantly, we adopt a consolidated view of the shadow banking sector, i.e. money market mutual funds invest in commercial paper that fund security brokers-dealers that provide credit. We view this intermediation chain as essentially being carried out by one intermediary. In our definition of shadow banks, we abstract from shadow banks as a form of commercial banks' off-balance sheet vehicles as our focus is on liquidity provision of banks.
} 
and leverage. However, the aggregate banking system becomes safer. Welfare is maximized at a capital requirement of roughly $15 \%$.

We derive this result in a production economy with households, commercial banks, shadow banks, capital goods producers, and a regulator. ${ }^{3}$ The main features of our model are riskneutral heterogeneous banks that make productive investments, have the option to default, and differ in their ability to guarantee the safety of their liabilities. At the same time, riskaverse households have preferences for safe and liquid assets in the form of bank liabilities whose liquidity value depends on their safety. Matching the model to aggregate data from the Flow of Funds as well as the Federal Reserve, Moody's, and the FDIC, we find an optimal capital requirement for commercial banks that is higher compared to current regulation. The optimal requirement finds the welfare maximizing balance between a reduction in liquidity services and the increase in the safety of the financial sector and consumption.

Key to this result are (i) the different economic forces that determine the leverage of each type of bank, and (ii) the relative quality of the liquidity services produced by either type of bank. The model economy features two production technologies for the consumption good. One technology is accessed by households directly through their ownership of a tree that produces an endowment of the good stochastically. The second technology is a linear, stochastic production technology that uses capital owned by intermediaries. Banks compete over capital shares and intermediate access to the capital's payoff. Their assets are funded by issuing equity and debt to households. When either type of bank defaults on its debt, its equity becomes worthless and a fraction of the remaining bank value is destroyed in bankruptcy.

Shadow bank debt is risky for households because the government only randomly bails out shadow banking debt. Moreover, following Allen and Gale (1994), a fraction of depositors

\footnotetext{
${ }^{3}$ Figure 1 gives an overview of the model.
} 
may run on shadow bank debt which requires shadow banks to sell off a fraction of their assets in a fire-sale. This fraction is endogenous and depends negatively on the fire sale discount and positively on shadow bank leverage. Thus, shadow bank leverage does not only increase the default probability of shadow banks but also the severity of bank runs during which their assets are less productive. Shadow bank debt is thus risky for investors, which they take into account. That is, the price at which shadow banks issue debt takes into account the default probability implied by their leverage choice, up to the random bailout chance. Shadow banks internalize this trade-off and limit their leverage endogenously. In contrast, commercial bank debt is insured and therefore always safe. However, commercial banks do not internalize that higher leverage makes costly bankruptcy more likely. Therefore, they do not take into account the social costs of higher leverage in the form of greater bankruptcy losses that the government imposes on households through lump sum taxation.

We match the model to aggregate data from the Flow of Funds on financial positions of U.S. households and financial institutions, interest rates from Federal Reserve Economic Data (FRED), and Compustat for publicly traded shadow banks (e.g. security-broker and dealers, finance companies).

Quantitatively, our results depend on household preferences for liquidity and the relative riskiness of shadow banks and commercial banks. Liquidity is affected by three key parameters: the share of liquidity services relative to consumption, the elasticity of substitution between shadow- and commercial banking debt, and the sensitivity of the liquidity quality of shadow banking debt with regard to the default rate in the shadow banking sector. We infer these parameters from an estimate for the convenience yield of government debt from Krishnamurthy and Vissing-Jorgensen (2012) that we apply to commercial banking debt, the share of shadow bank activity (1/3) estimated by Gallin (2013), and the rate on shadow banking that we proxy with the average quarterly rate of AA commercial paper from FRED, 
respectively.

The relative riskiness depends on the random bailout probability and the riskiness of banks' investment opportunities. As the bailout probability lowers the incentives of shadow banks to internalize the risk of their leverage choice, we infer the first parameter from the value weighted-average leverage of shadow banks using Compustat data, where the shadow bank definition includes security broker dealers, GSEs, finance- and investment companies. We target a $1 \%$ annual default rate for commercial banks and the cross-sectional volatilities of shadow and commercial banks' market-to-book ratios.

Increasing the capital requirement means that for every dollar of assets, commercial banks can issue fewer debt and produce less liquidity services, which reduces welfare. At the same, it reduces the bankruptcy rate of commercial banks and the associated deadweight losses. In an economy without shadow banks, this would be the key trade-off determining the optimal capital requirement.

In the economy with shadow banks, however, we find that higher capital requirements shift intermediation activity from commercial to shadow banks. The reduced liquidity production by commercial banks following tighter regulation increases the attractiveness of all types of bank liabilities as well as the value of banking in general. This causes the funding costs of shadow banks to decrease, and effectively increases shadow banks' demand for the intermediated capital. The resulting greater market share of shadow banks might offset the gain from making commercial banks safer through a higher capital requirement.

The net effect then crucially depends on the riskiness of shadow banks. If shadow banks are more fragile than commercial banks, the greater share of intermediation performed by shadow banks may dominate the gain in stability from safer commercial banks. However, in our calibrated model shadow banks are only moderately riskier than commercial banks and 
do not increase their leverage in response to the raised capital charge. The reason is that the quality of their liquidity services negatively depends on shadow bank default risk. Therefore the degree to which shadow bank liabilities can be substituted for insured deposits is limited, and shadow banks only partially replace the quantity of debt produced by commercial banks. Hence we find a net positive effect despite an expansion in shadow bank activity.

We also find that the exact level of the optimal capital requirement depends on the implicit bailout probability of shadow banks. If this probability is high, shadow banks are relatively risky, and there is only a limited gain from shifting intermediation activity to shadow banks through a greater capital requirement. In this case, which is our benchmark calibration, the optimal capital requirement is around 15 percent of assets. In a counterfactual scenario with a lower bailout probability for shadow banks, shadow banks act more efficiently and therefore pose less risk for financial instability if their intermediation share becomes larger. This leads to higher welfare gains when the capital requirement is increased. The dynamic model further shows that a greater deposit insurance fee for commercial banks does not lead to a safer financial system. While a higher fee shifts activity to the riskier shadow banks, it does not - unlike the capital requirement - make commercial banks sufficiently safer. Finally, we introduce a time-varying capital requirement that is set such that the expected default rate of commercial banks is lower than 25 basis point p.a. The resulting time-varying capital requirement has a mean of $13 \%$ and is tighter during booms, particularly during booms of the financial sector.

\section{Related Literature}

Our paper is part of a growing literature at the intersection of macroeconomics and banking that tries to understand optimal regulation of banks in a quantitative general equilibrium framework. ${ }^{4}$ Our modeling approach draws on the recent literature on the role of financial in-

\footnotetext{
${ }^{4}$ E.g. Begenau (2015), Christiano and Ikeda (2013), Elenev, Landvoigt, and Van Nieuwerburgh (2015),
} 
termediaries in the macroeconomy. ${ }^{5}$ These papers study economies with assets that investors can only access through an intermediary, as in our paper. The wealth of the intermediary then emerges as an additional state variable driving asset prices and the dynamics of the economy. By introducing limited liability and deposit insurance, and by defining the role of banks as liquidity producers, we bridge the gap to a long-standing microeconomic literature on the function of banks in the economy. Several recent papers in this literature study the interaction of different types of banks that differ in the extent of regulation and bailout guarantees. ${ }^{6}$

Our paper is most closely related to Moreira and Savov (2014), Huang (2015), and Gertler, Kiyotaki, and Prestipino (2016). Moreira and Savov (2014) study an intermediary asset pricing economy with two types of assets that differ in suitability as collateral for issuing safe and liquid liabilities (money). They demonstrate that the presence of shadow banks can lead to increased economic volatility as rational investors try to determine the liquidity of the debt issued by the financial sector. Huang (2015) models shadow banks as an off-balance sheet financing option for regular banks within the Brunnermeier and Sannikov (2014) framework. Financial stability is a U-shaped function of financial regulation (i.e. very tight regulation generates more off-balance activities). Gertler, Kiyotaki, and Prestipino (2016) construct a quantitative macro-finance framework with a role for both regular banks (retail) and shadow banks (wholesale). Bank runs occur endogenously and allow the model to capture important features of the recent financial crisis. Our definition of banks is closely related to Gertler, Kiyotaki, and Prestipino (2016). A key difference to other work is our focus on liquidity provision as a fundamental role of banking and moral hazard arising endogenously from Gertler, Kiyotaki, and Prestipino (2016). See Nguyen (2014) and Corbae and D'Erasmo (2014) for quantitative models in partial equilibrium.

${ }^{5}$ E.g. Brunnermeier and Sannikov (2014), He and Krishnamurthy (2013), Garleanu and Pedersen (2011), Adrian and Boyarchenko (2015), Moreira and Savov (2014).

${ }^{6}$ E.g. Goodhart, Kashyap, Tsomocos, and Vardoulakis (2012), Gennaioli, Shleifer, and Vishny (2013), Plantin (2014), Harris, Opp, and Opp (2015) 
deposit insurance and limited liability.

The paper is structured as follows. Section 2 describes the model and section 3 the main mechanism. Section 4 shows how we map the model to the data and presents the policy experiments.

\section{A Model of the Banking System}

This section presents the general equilibrium model economy. For a quick overview of the model see Figure 1. We discuss the key assumptions of the model in section 2.2.

The basic structure of the model is as follows. Households maximize utility from consuming goods and liquidity services. The economy receives an endowment of the consumption good which households directly own. Further, the economy features productive capital which households can only access through financial intermediaries. Two types of intermediaries, C-banks and S-banks, can perform the intermediation. That is, they each hold a fraction

of the aggregate capital stock and produce the consumption good using a linear stochastic production technology. New capital is produced by capital goods producers who sell it to intermediaries. Banks issue short-term debt and equity to households to fund the purchase of capital. The short term debt of both banks provides households with liquidity services.

Both type of banks can declare bankruptcy and default on their debt. However, the debt of C-banks is riskfree to households since the government provides deposit insurance for Cbanks. In return, C-banks are subject to capital regulation. S-banks, on the other hand, are not subject to regulation that limits their leverage. Their debt is risky for households since debt of defaulting S-banks only pays off a fraction of the face value. S-banks take into account the effect of their leverage choice on the expected payoff of their debt, and hence endogenously choose to limit their leverage. Moreover, a fraction of households may run on 


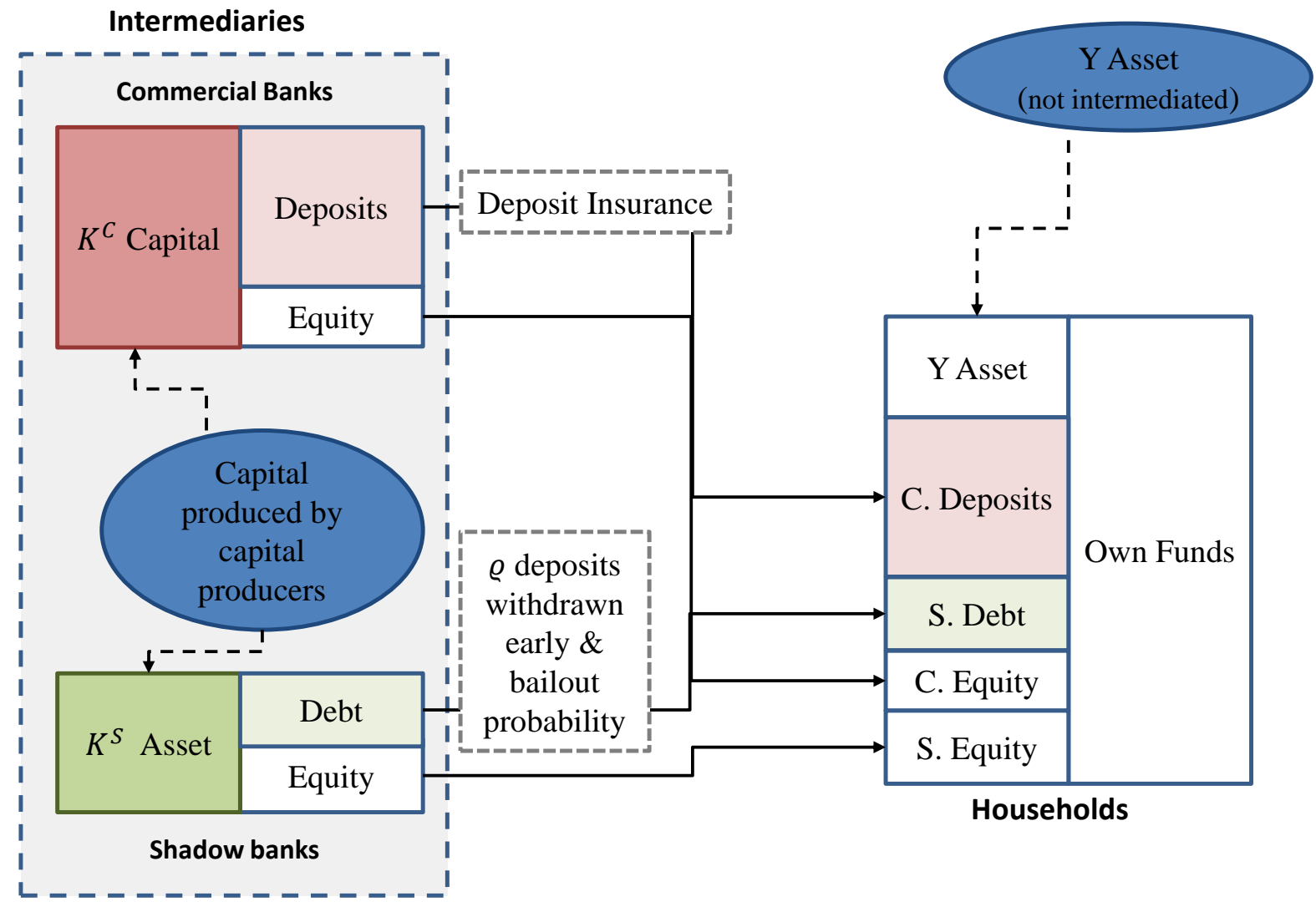

Figure 1: Model Overview

shadow bank debt forcing a fraction of shadow banks' assets into a fire sale that lowers their productivity.

\subsection{Detailed Model Description}

Agents and Environment Time is discrete and infinite. Households receive stochastic income from a tree, $Y_{t}$. In addition, the economy has a capital stock $K_{t}$, with each unit of capital producing output $Z_{t}$. Capital is produced by capital goods producers that sell new capital to intermediaries. After producing, capital depreciates at the rate $\delta_{K}$. Households 
do not own this type of capital directly. Rather, the two types of intermediaries finance purchases of this capital by issuing equity and debt to households. This captures the idea that households use banks to finance durable goods such as housing and cars. Banks have limited liability, i.e., they can choose to declare bankruptcy. Shadow banks are subject to partial bank runs, in the sense that a fraction of depositors may decide to withdraw their funds before the payoff of the assets is realized, and forcing the shadow bank to liquidate part of their assets in fire-sales. Deposit insurance prevents bank runs on commercial banks.

Investment There is a capital producing firm that is fully owned by households and maximizes its profit $\Pi_{t}^{I}$. This firm can buy units of the consumption good and turns them into units of capital (that produce output $Z_{t}$ ). To generate $I_{t}$ units of capital, the capital-producing firm needs to expend

$$
I_{t}+\Phi\left(I_{t}\right)
$$

units of the consumption good, with $\Phi^{\prime}\left(I_{t}\right)>0, \Phi^{\prime \prime}\left(I_{t}\right)>0$, and $\Phi(0)=0$.

$S$-Banks There is a unit mass of $S$-banks, indexed by $i . S$-bank $i$ holds $K_{t, i}^{S}$ units of capital at the beginning of period $t$. The shares trade at a market price of $p_{t}$. To fund their investment, $S$-banks can issue short term debt. The debt of $S$-bank $i$ trades at the price $q_{t, i}^{S}$. At the beginning of the period, $S$-bank $i$ has $B_{t, i}^{S}$ bonds outstanding.

The payoff per unit of capital held by bank $i$ is $Z_{t}$. Each period, $S$-banks face idiosyncratic valuation risks $\rho_{t, i}^{S}$ that are proportional to the market value of their assets, with $\rho_{t, i}^{S} \sim F_{\rho}^{S}$ and $\mathrm{E}\left(\rho_{t, i}^{S}\right)=1$, i.i.d. across banks and time. At the beginning of each period (after observing $\left.\rho_{t, i}^{S}\right), S$-banks can decide to declare bankruptcy. In case of a bankruptcy, banks' equity is wiped out, and their assets are seized by their creditors. Further, the bank's managers incur a utility penalty, that is, a fraction $\delta_{S}$ of the value of the bank's assets. 
We define book leverage $b_{t, i}^{S}=\frac{B_{t, i}^{S}}{K_{t, i}^{S}}$ and market leverage

$$
L_{t, i}^{S}=\frac{B_{t, i}^{S}}{K_{t, i}^{S}\left(Z_{t}+\left(1-\delta_{K}\right) p_{t}\right)}=\frac{b_{t, i}^{S}}{\left(Z_{t}+\left(1-\delta_{K}\right) p_{t}\right)}
$$

Shadow banks are exposed to aggregate run-risk. That is, a fraction of shadow bank deposits $\varrho$ is withdrawn early within a given period (affecting all shadow banks equally), where $\varrho_{t}^{S} \in\left\{0, \varrho^{*}>0\right\}$, following a two-state Markov chain. When deposits are withdrawn, shadow banks need to liquidate a fraction $\ell_{t, i}^{S}$ of their assets. Assets that are liquidated early are sold at price $\underline{p}_{t}$ in a separate market at the beginning of the period and do not yield any payoff to the bank. The buyers of these assets are households. Households have an inferior ability to operate the asset, leading to a lower payoff $\underline{Z}_{t}<Z_{t}$ and a higher depreciation rate $\underline{\delta}_{K}>\delta_{K}$. Households sell the asset again in the regular market later in the same period. Household optimization implies that the fire-sale price is ${ }^{7}$

$$
\underline{p}_{t}=\left(1-\underline{\delta}_{K}\right) p_{t}+\underline{Z}_{t}
$$

We define the fire-sale discount

$$
x_{t}=\frac{\left(1-\underline{\delta}_{K}\right) p_{t}+\underline{Z}_{t}}{\left(1-\delta_{K}\right) p_{t}+Z_{t}}<1 .
$$

To pay out its depositors in case of a withdrawal shock $\left(\varrho_{t}^{S}=\varrho^{*}\right)$, the bank must sell $\varrho^{*} B_{t}^{S}$ worth of assets. We assume that the liquidation sale takes place before the realization of the idiosyncratic shock $\rho_{t, i}^{S}$ and the bankruptcy decision. Hence the fraction of assets that needs to be liquidated is

$$
\ell_{t, i}^{S}=\frac{\varrho_{t}^{S} B_{t, i}^{S}}{K_{t, i}^{S} \underline{p}_{t}}=\frac{\varrho_{t}^{S} L_{t, i}^{S}}{x_{t}},
$$

using the definition of leverage and the fire-sale discount.

\footnotetext{
${ }^{7}$ Since both transactions take place within the same period and households are unconstrained, it immediately follows that $\underline{p}_{t}$ must be equal to the marginal product of capital to households, which is equivalent to equation (2). Also, note that the marginal product of capital to households is always lower than that of firms, so households do never optimally own any capital at the end of the period.
} 
Since the idiosyncratic valuation shocks are uncorrelated over time, it is convenient to write the optimization problem of surviving banks after the bankruptcy decision and asset payoffs. All banks have the same value and face identical problems:

$$
\begin{aligned}
\max _{K_{t+1}^{S}, B_{t+1}^{S}} & q_{t}^{S} B_{t+1}^{S}-p_{t} K_{t+1}^{S} \\
+ & \mathrm{E}_{t}\left[M _ { t , t + 1 } \operatorname { m a x } \left\{\rho _ { t + 1 } ^ { S } K _ { t + 1 } ^ { S } \left(\ell_{t+1}^{S} \underline{p}_{t+1}+\right.\right.\right. \\
& \left.\left.\left.+\left(1-\ell_{t+1}^{S}\right)\left(Z_{t+1}+\left(1-\delta_{K}\right) p_{t+1}\right)\right)-B_{t+1}^{S},-\delta_{S} K_{t+1}^{S}\left(Z_{t+1}+\left(1-\delta_{K}\right) p_{t+1}\right)\right\}\right] .
\end{aligned}
$$

Using the definitions for book- and market leverage we rewrite the maximum operator, i.e. the continuation value, as

$$
\begin{aligned}
& K_{t}^{S} \max \left\{\rho_{t}^{S}\left(\ell_{t}^{S} \underline{p}_{t}+\left(1-\ell_{t}^{S}\right)\left(Z_{t}+\left(1-\delta_{K}\right) p_{t}\right)\right)-b_{t}^{S},-\delta_{S}\left(Z_{t}+\left(1-\delta_{K}\right) p_{t}\right)\right\} \\
& =K_{t}^{S}\left(Z_{t}+\left(1-\delta_{K}\right) p_{t}\right)\left(1\left[\rho_{t}^{S} \geq \frac{L_{t}^{S}-\delta_{S}}{1-\ell_{t}^{S}\left(1-x_{t}\right)}\right]\left(\rho_{t}^{S}\left(1-\ell_{t}^{S}\left(1-x_{t}\right)\right)-L_{t}^{S}\right)\right. \\
& \left.-1\left[\rho_{t}^{S}<\frac{L_{t}^{S}-\delta_{S}}{1-\ell_{t}^{S}\left(1-x_{t}\right)}\right] \delta_{S}\right) .
\end{aligned}
$$

Taking the expectation of this expression with respect to $\rho_{t}^{S}$, one obtains

$$
\underbrace{\left[\left(1-F_{\rho}^{S}\left(\frac{L_{t}^{S}-\delta_{S}}{1-\ell_{t}^{S}\left(1-x_{t}\right)}\right)\right)\left(\rho_{t}^{S,+}\left(1-\ell_{t}^{S}\left(1-x_{t}\right)\right)-L_{t}^{S}\right)-F_{\rho}^{S}\left(\frac{L_{t}^{S}-\delta_{S}}{1-\ell_{t}^{S}\left(1-x_{t}\right)}\right) \delta_{S}\right]}_{: \equiv \mathcal{F} S\left(L_{t}^{S}\right)}
$$

where $\rho_{t}^{S,+}=\mathrm{E}\left(\rho_{t}^{S} \mid \rho_{t}^{S}>\frac{L_{t}^{S}-\delta_{S}}{1-\ell_{t}^{S}\left(1-x_{t}\right)}\right), F_{\rho}^{S}\left(\frac{L_{t}^{S}-\delta_{S}}{1-\ell_{t}^{S}\left(1-x_{t}\right)}\right)$ is the probability of default, and $\mathcal{F}^{S}\left(L_{t}^{S}\right)$ describes the leverage- and run-adjusted payoff of S-banks' portfolio, including the default option. The payoff is higher the lower banks' leverage, the lower the fraction of liquidated assets $\ell_{t}$, the closer fire-sale prices are to regular market prices $x_{t}$, and the lower the utility penalty.

We can now define the per-asset value function

$$
v^{S}\left(Z_{t}\right)=\max _{b_{t+1}^{S}} q_{t}^{S} b_{t+1}^{S}-p_{t}+\mathrm{E}_{t}\left[M_{t, t+1}\left(Z_{t+1}+\left(1-\delta_{K}\right) p_{t+1}\right) \mathcal{F}^{S}\left(L_{t+1}^{S}\right)\right]
$$


such that the full optimization problem of the S-bank is given by

$$
\max _{K_{t+1}^{S}} K_{t+1}^{S} v^{S}\left(Z_{t}\right)
$$

subject to $K_{t+1}^{S} \geq 0$.

$C$-Banks There is a unit mass of $C$-banks. $C$-banks are different from $S$-banks in three ways: (i) they issue short-term debt that is insured and risk free from the perspective of creditors, (ii) they are subject to regulatory capital requirements, and (iii) they are not subject to run risk, i.e. $\varrho_{t}^{C}=0$ and thus $\ell_{t}^{C}=0 \forall t$. They pay an insurance fee of $\kappa$ for each bond they issue. Using the same notation as for S-banks, the problem of all surviving $C$-banks is identical and given by

$$
\max _{K_{t+1}^{C}} K_{t+1}^{C} v^{C}\left(Z_{t}\right)
$$

subject to $K_{t+1}^{C} \geq 0$, and where the per-asset value is given by

$$
v^{C}\left(Z_{t}\right)=\max _{b_{t+1}^{C}}\left(q_{t}^{C}-\kappa\right) b_{t+1}^{C}-p_{t}+\mathrm{E}_{t}\left[M_{t, t+1}\left(Z_{t+1}+\left(1-\delta_{K}\right) p_{t+1}\right) \mathcal{F}\left(L_{t+1}^{C}\right)\right]
$$

subject to the equity requirement

$$
(1-\theta) p_{t} \geq b_{t}^{C}
$$

Bankruptcy The idiosyncratic asset valuation shock is realized at the beginning of each period before any decisions have been made.

If a bank declares bankruptcy, its equity becomes worthless, and creditors seize all of the banks assets, which are liquidated. The recovery amount per bond issued is hence

$$
\begin{aligned}
r^{j}\left(L_{t}^{j}\right) & =\left(1-\xi^{j}\right) \frac{\rho_{t}^{j,-}\left(\ell_{t}^{j} \underline{p}_{t}+\left(1-\ell_{t}^{j}\right)\left(Z_{t}+\left(1-\delta_{K}\right) p_{t}\right)\right) K_{t}^{j}}{B_{t}^{j}} \\
& =\left(1-\xi^{j}\right) \frac{\rho_{t}^{j,-}\left(1-\ell_{t}^{j}\left(1-x_{t}\right)\right)}{L_{t}^{j}},
\end{aligned}
$$


for $j=S, C$, with a fraction $\xi^{j}$ lost in the bankruptcy proceedings, and with $\rho_{t}^{j,-}=$ $\mathrm{E}\left(\rho_{t}^{j} \mid \rho_{t}^{j}<\left(\frac{L_{t}^{j}-\delta_{j}}{1-\ell_{t}^{S}\left(1-x_{t}\right)}\right)\right)$. For shadow banks the recovery value is also decreasing in the amount of assets that need to be liquidated as well as the discount $\left(\operatorname{smaller} x_{t}\right)$. After the bankruptcy proceedings are completed, a new bank is set up to replace the failed one. This bank sells its equity to new owners, and is otherwise identical to a surviving bank after asset payoffs.

If a $S$-bank defaults, the recovery value per bond is used to pay the claims of bondholders to the extent possible. We further consider the possibility that the government bails out the bond holders of the defaulting $S$-bank with a probability $\pi_{B}$, known to all agents ex ante. If a $C$-bank declares bankruptcy, the bank is taken over by the government that uses lump sum taxes and revenues from deposit insurance, $\kappa B_{t+1}^{C}$, to pay out the bank's creditors in full. Summing up over defaulting $C$-banks and $S$-banks that are bailed out, lump sum taxes are defined

$$
T_{t}=F_{\rho, t}^{C}\left(1-r^{C}\left(b_{t}^{C}\right)\right) B_{t}^{C}-\kappa B_{t+1}^{C}+\pi_{B} F_{\rho, t}^{S}\left(1-r^{S}\left(b_{t}^{S}\right)\right) B_{t}^{S}
$$

The beginning-of period dividend paid by banks to households, conditional on survival, for $S$-banks is

$$
D_{t}^{S}=\rho_{t}^{S,+} K_{t}^{S}\left(\ell_{t}^{S} \underline{p}_{t}+\left(1-\ell_{t}^{S}\right)\left(Z_{t}+\left(1-\delta_{K}\right) p_{t}\right)\right)-B_{t}^{S}+K_{t+1}^{S}\left(q_{t}^{S} b_{t+1}^{S}-p_{t}\right)
$$

and for $C$-banks

$$
D_{t}^{C}=\rho_{t}^{C,+} K_{t}^{C}\left(Z_{t}+\left(1-\delta_{K}\right) p_{t}\right)-B_{t}^{C}+K_{t+1}^{C}\left(\left(q_{t}^{C}-\kappa\right) b_{t+1}^{C}-p_{t}\right)
$$

Households Households derive utility from the consumption $C_{t}$ of the fruit of the $Y$-tree and the fraction of output $Z_{t} K_{t}$ that is not invested. Households hold a portfolio of all securities that both types of intermediaries issue. In particular, they buy equity shares of 
both types of intermediaries, $S_{t}^{j}$, that trade at price of $p_{t}^{j}$, for $j=S, C$ respectively. They further buy the short terms bonds both types issue, $N_{t}^{j}$, trading at prices $q_{t}^{j}$, for $j=S, C$.

Households consume the liquidity services provided by the short term debt they hold at the beginning of the period. This reflects that the liquidity services accrue at the time when the deposits from last period are redeemed. Let $N_{t}^{j}=\int_{0}^{1} N_{t, i}^{j} d i$, for $j=S, C$. Then the total liquidity services produced are

$$
H\left(N_{t}^{S}, N_{t}^{C}\right)
$$

and household utility in period $t$ is

$$
U\left(C_{t}, H\left(N_{t}^{S}, N_{t}^{C}\right)\right)
$$

We specify utility as

$$
U\left(C_{t}, H\left(N_{t}^{S}, N_{t}^{C}\right)\right)=\frac{\left.\left(C_{t}^{(} 1-\psi\right) H_{t}^{\psi}\right)^{1-\gamma}}{1-\gamma}
$$

with

$$
H\left(N_{t}^{S}, N_{t}^{C}\right)=\left[\Lambda_{S, t}\left(N_{t}^{S}\right)^{\alpha}+\left(N_{t}^{C}\right)^{\alpha}\right]^{1 / \alpha}
$$

The elasticity of substitution between the two types of bank liabilities is $1 /(1-\alpha)$.

We define the weight on the liquidity services of shadow banks $\Lambda_{S, t}$ as follows:

$$
\Lambda_{S, t}=\left(1-F_{\rho, t}^{S}\right)^{\nu}
$$

with $\nu>0$. The liquidity productivity of shadow banks is lower than that of commercial banks. The discount depends on the fraction of surviving shadow banks, introducing endogenous time-variation in the quality of liquidity services.

Households further receive the profit $\Pi_{t}^{I}$ of the capital producing firm. 
Denoting household wealth at the beginning of the period by $W_{t}$, the complete intertemporal problem of households is

$$
V^{H}\left(W_{t}, Y_{t}, N_{t}^{S}, N_{t}^{C}\right)=\max _{C_{t}, N_{t}^{S}, N_{t}^{C}, S_{t}^{S}, S_{t}^{C}} U\left(C_{t}, H\left(N_{t}^{S}, N_{t}^{C}\right)\right)+\beta \mathrm{E}_{t}\left[V\left(W_{t+1}, Y_{t+1}\right)\right]
$$

subject to

$$
\begin{aligned}
W_{t}+Y_{t} & +\Pi_{t}^{I}-T_{t}=C_{t}+\sum_{j=S, C} p_{t}^{j} S_{t}^{j}+\sum_{j=S, C} q_{t}^{j} N_{t}^{j} \\
W_{t+1}= & \sum_{j=S, C}\left(1-F_{\rho}^{j}\left(L_{t+1}^{j}\right)\right)\left(D_{t+1}^{j}+p_{t+1}^{j}\right) S_{t}^{j} \\
& +N_{t}^{S}\left[1-F_{\rho}^{S}\left(L_{t+1}^{S}\right)+F_{\rho}^{S}\left(L_{t+1}^{S}\right)\left(\pi_{B}+\left(1-\pi_{B}\right) r_{t+1}^{S}\right)\right] \\
& +N_{t}^{C} .
\end{aligned}
$$

The budget constraint in equation (7) shows that households spend their wealth and income on consumption and purchases of equity and debt of both types of intermediaries. The securities issued are the same for all banks, independent of the previous bankruptcy status. The equity purchases for banks that have gone through bankruptcy at the beginning of period $t$ can be understood as initial equity offerings for these banks, while the purchases of equity of surviving banks are in a secondary market. However, since both new and surviving banks hold identical portfolios, their securities have the same price and there is no need to distinguish primary and secondary markets. ${ }^{8}$

\footnotetext{
${ }^{8}$ It is possible to show that the price to an equity claim of bank types $j, p_{t}^{j}$, is equal to the value of that bank's security portfolio, $K_{t+1}^{j} p_{t}-q_{t}^{j} B_{t+1}^{j}$.
} 
Market Clearing Asset markets

$$
\begin{aligned}
K_{t+1}^{S}+K_{t+1}^{C} & =I_{t}+\left(1-\delta_{K}\right)\left(1-\xi^{C} F_{\rho, t}^{C} \rho_{t}^{C,-}\right) K_{t}^{C} \\
& +\left(1-\delta_{K}-\ell_{t}^{S}\left(\underline{\delta}_{K}-\delta_{K}\right)\right)\left(1-\xi^{S} F_{\rho, t}^{S} \rho_{t}^{S,-}\right) K_{t}^{S} \\
B_{t}^{S} & =N_{t}^{S} \\
B_{t}^{C} & =N_{t}^{C} \\
S_{t}^{S} & =1 \\
S_{t}^{C} & =1 .
\end{aligned}
$$

Goods market

$$
\begin{aligned}
C_{t} & =Y_{t}-I_{t}-\Phi\left(I_{t}\right)+Z_{t}\left(1-\xi^{C} F_{\rho, t}^{C} \rho_{t}^{C,-}\right) K_{t}^{C} \\
& +\left(Z_{t}-\ell_{t}^{S}\left(Z_{t}-\underline{Z}_{t}\right)\right)\left(1-\xi^{S} F_{\rho, t}^{S} \rho_{t}^{S,-}\right) K_{t}^{S} .
\end{aligned}
$$

The market clearing condition for capital in (10) is also the transition law for the aggregate capital stock. Note that bank failures lead to additional depreciation that is endogenously determined through the failure rates of banks, $F_{\rho}^{j}\left(L_{t}^{j}\right)$. Similarly, bank failures also lead to an output loss in the goods market, as can be seen in market clearing condition for consumption goods (12).

\subsection{Discussion of assumptions}

Banks' Role as Intermediaries In the model, banks are special because they provide liquidity (discussed below) and also help to produce the consumption good. The role of banks as intermediaries can be derived from first principles in numerous ways. For example, in models with asymmetric information between borrowers and lenders, lenders with access to a cheaper screening or monitoring technology than other lenders (regular households) become banks (see Freixas and Rochet (1998) for many other examples). In our formulation 
banks own the production technology directly which is similar to Brunnermeier and Sannikov (2014), that is we abstract from any frictions between producers and banks.

The Role of Banks as Liquidity Providers In this model, households value bank debt because it is liquid ${ }^{9}$ and safe, an interpretation of bank debt in Gorton and Pennacchi (1990) and in Gorton et al. (2012). The notion of safe and liquid assets includes bank deposits, money market fund shares, commercial paper, repos, short-term interbank loans, Treasuries, agency and municipal debt, securitized debt, and high-grade financial sector corporate debt. Aside from the government, commercial banks and shadow banks are the most important providers of these securities. ${ }^{10}$ The savings glut hypothesis articulated in Bernanke (2005) and other recent work (e.g. Caballero and Krishnamurthy (2009), Gorton, Lewellen, and Metrick (2012), and Krishnamurthy and Vissing-Jorgensen (2012)) rests on the notion that there exists a demand for safe and liquid securities. Economic agents demanding these assets are for example households that hold deposits for transaction or liquidity reasons as well as corporations, institutional investors, and high net worth individuals that carry large cash-balances and seek safe and liquid investment vehicles with higher yields than deposits, such as money market mutual funds. Commercial banks provide mostly deposits, but also issue money market fund shares, repos, and commercial paper. Some of these securities that commercial banks hold (most notably deposits) are explicitly insured through deposit insurance. Others, such as money market fund shares and commercial papers are indirectly insured due to government guarantees. ${ }^{11}$ Shadow banks generally do not benefit from government guarantees. Nevertheless outside of recessions and banking crisis, money

\footnotetext{
${ }^{9}$ The idea to view banks as liquidity provider goes back to Diamond and Dybvig (1983). Other work has built upon this idea (e.g. Gorton and Pennacchi (1990)).

${ }^{10}$ Historically, money market mutual funds (a type of shadow bank) emerged precisely to satisfy demand for safe and liquid assets when Regulation Q imposed a ceiling on deposit rates.

${ }^{11} \mathrm{~A}$ number of empirical papers presents evidence for market expectations for government guarantees on U.S. banks (see for instance Flannery and Sorescu (1996) and Gandhi and Lustig (2013)).
} 
market mutual funds shares and collateralized short term funding sources such as repo are considered safe and liquid.

In the model, liquidity services are generated through debt issued by shadow banks and commercial banks. Commercial bank debt represents all commercial bank liabilities precisely because the demand for safe and liquid assets goes beyond merely deposits. We apply the same idea to shadow bank debt with one notable difference: the value of shadow bank liabilities depends on the likelihood at which shadow banks default.

Liquidity services in households preference We capture the idea that bank liabilities provide liquidity services with our utility specification. The households in our model represent a blend of different agents with demands for different types of safe and liquid assets (deposits, money market mutual fund shares, and so forth) provided by all financial institutions. This is why our utility specification aggregates the liquidity services of both bank types.

Commercial bank debt always provides liquidity services no matter their default probability. This is different for shadow banks as the value from their liquidity service depends on their probability of default. This captures the idea that shadow bank debt is only safe as long as shadow banks are safe, that is, not too many of them go bankrupt.

The demand for liquidity services is captured with a money-in-the-utility function specification. Since Sidrauski (1967) money-in-the-utility specifications have been used to capture the benefits from money-like-securities for households in macroeconomic models. Feenstra (1986) proved the functional equivalence of models with money-in-the-utility and models with transaction or liquidity costs. The specific functional form is a version of Poterba and Rotemberg (1986). 


\subsection{Equilibrium Characterization}

This section characterizes the equilibrium, i.e. stating the important first order conditions.

Capital Good Producers Capital goods producers maximize profits each period by choosing investment output

$$
\max _{I_{t}} p_{t} I_{t}-I_{t}-\Phi\left(I_{t}\right)
$$

which yields the typical first-oder condition tying the price of capital to the marginal cost of investment

$$
p_{t}=1+\Phi^{\prime}\left(I_{t}\right)
$$

Household The household's first-order conditions for purchases of bank equity are, for $j=S, C$,

$$
p_{t}^{j}=\mathrm{E}_{t}\left[M_{t, t+1}\left(1-F_{\rho}^{j}\left(L_{t+1}\right)\right)\left(D_{t+1}^{j}+p_{t+1}^{j}\right)\right],
$$

where we have defined the stochastic discount factor

$$
M_{t, t+1}=\beta \frac{U_{1}\left(C_{t+1}, H_{t+1}\right)}{U_{1}\left(C_{t}, H_{t}\right)} .
$$

We further define the intratemporal marginal rate of substitution between consumption and liquidity services

$$
Q_{t}=\frac{U_{2}\left(C_{t}, H_{t}\right)}{U_{1}\left(C_{t}, H_{t}\right)},
$$

where

$$
\begin{aligned}
& U_{1}=(1-\psi) C^{(1-\gamma)(1-\psi)-1} H^{\psi(1-\gamma)} \\
& U_{2}=\psi C^{(1-\gamma)(1-\psi)} H^{(1-\gamma) \psi-1}
\end{aligned}
$$


and consequently

$$
Q_{t}=\frac{\psi}{1-\psi} \frac{C_{t}}{H_{t}}
$$

Then the first-order conditions for purchases of bonds of either type of bank are

$$
\begin{aligned}
& q_{t}^{C}=Q_{t} \Lambda_{C, t}\left(\frac{H_{t}}{N_{t}^{C}}\right)^{1-\alpha}+\mathrm{E}_{t}\left[M_{t, t+1}\right] \\
& q_{t}^{S}=Q_{t} \Lambda_{S, t}\left(\frac{H_{t}}{N_{t}^{S}}\right)^{1-\alpha}+E_{t}\left\{M_{t, t+1}\left[1-F_{\rho}^{S}\left(L_{t+1}^{S}\right)+F_{\rho}^{S}\left(L_{t+1}^{S}\right)\left(\pi_{B}+\left(1-\pi_{B}\right) r^{S}\left(L_{t+1}^{S}\right)\right)\right]\right\} .
\end{aligned}
$$

The payoff of commercial bank bonds is 1, whereas the payoff of shadow bank bonds depends on their default probability and recovery value. The first terms in each expression represent the marginal benefit of liquidity services to households.

Banks $S$-banks are subject to an endogenous borrowing constraint. Each $S$-bank is effectively a monopolist for its own debt, as it internalizes the effect of supplying additional bonds on the bond price.

Specifically, each $S$-bank views the price of its debt as a function of its supply of bonds $q_{t}^{S}=q\left(b_{t+1}^{S}\right)$ that is determined by households' first order condition in equation 16 .

It follows from differentiating equation (3) that the FOC of $S$-banks for leverage is ${ }^{12}$

$$
q\left(b_{t+1}^{S}\right)+b_{t+1}^{S} q^{\prime}\left(b_{t+1}^{S}\right)=\mathrm{E}_{t}\left[M_{t+1}\left(1-F_{t+1}^{S}\right)\left(1+\ell_{t+1}\left(1-x_{t+1}\right) \frac{\rho_{t+1}^{S,+}}{L_{t+1}^{S}}\right)\right]
$$

The partial derivative $q^{\prime}\left(b_{t+1}^{S}\right)$ can be obtained directly from households' FOC for purchases of shadow bank debt. Differentiating equation (16) yields

\footnotetext{
${ }^{12}$ Appendix A.1 contains details of the derivations in this section.
} 


$$
\frac{\partial q^{S}\left(b_{t+1}^{S}\right)}{\partial b_{t+1}^{S}}=-\mathrm{E}_{t}\left\{\left(1-\pi_{B}\right) M_{t, t+1}\left[\frac{F_{t+1}^{S} r_{t+1}^{S}}{b_{t+1}^{S}\left(1-\ell_{t+1}\left(1-x_{t+1}\right)\right)}+\frac{f_{t+1}^{S}}{b_{t+1}^{S}} \mathcal{L}^{S}\left(L_{t+1}^{S}\right)\left(\left(1-\xi_{S}\right) \delta_{S}+\xi_{S} L_{t+1}^{S}\right)\right]\right\}
$$

where

$$
\mathcal{L}^{S}\left(L_{t+1}^{S}\right)=\frac{1-\delta_{S} \ell_{t+1} \frac{1-x_{t+1}}{L_{t+1}^{S}}}{\left(1-\ell_{t+1}\left(1-x_{t+1}\right)\right)^{2}}
$$

The RHS of equation 18 is strictly negative, implying that the price of shadow bank debt is decreasing in shadow bank leverage $b_{t+1}^{S}$. The first term reflects that the recovery value per bond in case of bankruptcy decreases if the shadow bank issues more debt. The second term is the loss for lenders from a marginal increase in the probability of default.

S-bank leverage $L_{t+1}^{S}$ is determined by combining equations (17) and (18), and substituting for the bond price from households' first-order condition (16).

The debt price of commercial banks is independent of their leverage choice. Therefore the FOC of $C$-banks for leverage is

$$
q_{t}^{C}-\kappa=\lambda_{t}^{C}+\mathrm{E}_{t}\left[M_{t, t+1}\left(1-F_{\rho, t+1}^{C}\right)\right]
$$

with $\lambda_{t}^{C}$ being the Lagrange multiplier on the leverage constraint in equation (5). This FOC and the household FOC for purchases of commercial bank debt (15) jointly imply that the Lagrange multiplier is positive and hence the $C$-bank leverage constraint is binding, i.e.

$$
(1-\theta) p_{t}=b_{t}^{C}
$$

To be precise, the condition ${ }^{13}$ for a binding leverage requirement is

$$
\lambda_{t}^{C}=Q_{t} \Lambda_{C, t}\left(\frac{H_{t}}{N_{t}^{C}}\right)^{1-\alpha}+\mathrm{E}_{t}\left[M_{t, t+1} F_{\rho, t+1}^{C}\right]-\kappa>0 .
$$

\footnotetext{
${ }^{13}$ This condition is derived from combining the FOC of commercial banks with respect to leverage with household's FOC with respect to debt.
} 
The first term is the marginal value of liquidity services derived from commercial bank deposits. As long as households are not satiated with liquidity, the marginal value is positive. The second term is the expected discounted value in case of default of carrying one unit of resources into the next period, which is positive as long as commercial banks default with some probability $F_{\rho, t+1}^{C}>0$. The last term is the deposit insurance fee. Taken together, this means that a small enough $\kappa$ implies that the leverage requirement will always bind. This is the case for the parametrization we consider. ${ }^{14}$

The first-order conditions for asset purchases $K_{t+1}^{j}$ follow from the constant returns to scale (i.e. zero-profit) nature of each type's problem, requiring $v^{S}\left(Z_{t}\right)=0$ and $v^{C}\left(Z_{t}\right)=0$, respectively, which yields

$$
\begin{aligned}
& p_{t}=q_{t}^{S} b_{t+1}^{S}+\mathrm{E}_{t}\left[M_{t, t+1}\left(Z_{t+1}+\left(1-\delta_{K}\right) p_{t+1}\right) \mathcal{F}^{S}\left(L_{t+1}^{S}\right)\right], \\
& p_{t}=\left(q_{t}^{C}-\kappa\right) b_{t+1}^{C}+\mathrm{E}_{t}\left[M_{t, t+1}\left(Z_{t+1}+\left(1-\delta_{K}\right) p_{t+1}\right) \mathcal{F}^{C}\left(L_{t+1}^{C}\right)\right] .
\end{aligned}
$$

\section{Main Mechanism}

This section describes the main mechanism in the deterministic version of the model. Banks have to choose their size (capital stock share) and leverage.

Banks' leverage choice The leverage choice of C-banks is determined by their FOC for $b^{C}$

$$
q^{C}-\kappa=\lambda^{C}+\beta\left(1-F^{C}\right) .
$$

\footnotetext{
${ }^{14}$ Conversely, if a regulator could set

$$
\kappa>M R S_{C, t}+\mathrm{E}_{t}\left[M_{t, t+1} F_{\rho, t+1}^{C}\right] \forall t,
$$
}

commercial banks may never choose leverage at the regulatory limit. 
Combining equation 20 with households' FOC with respect to $N^{C}$

$$
q^{C}=\underbrace{Q \Lambda_{C}\left(\frac{H}{N^{C}}\right)^{1-\alpha}}_{: \equiv M R S_{C}}+\beta
$$

one obtains

$$
\lambda^{C}=M R S_{C}+\beta\left[F^{C}\right]-\kappa>0
$$

for small enough values of $\kappa$. In other words, commercial banks' leverage constraint is always binding in the steady state.

As for C-banks, S-bank leverage per unit of assets is determined trough S-banks' FOC for $b^{S}$, which in the steady state with $\ell=0$ can be written as

$$
q\left(b^{S}\right)+b^{S} q^{\prime}\left(b^{S}\right)=\beta\left(1-F^{S}\right) .
$$

Comparing the FOC for C-bank leverage in (20) to the S-bank FOC in (22) above reveals the fundamental difference between the two types of banks. While C-banks are subject to a constant leverage constraint that in equilibrium is always binding, S-banks choose to limit their leverage because they internalize the effect of their leverage choice on the price of their deposits, $q^{S}$.

Increasing leverage $b^{S}$ will decrease the survival probability $F^{S}$ and hence lower the value of S-bank deposits to HH, implying $\frac{\partial q^{S}\left(b^{S}\right)}{\partial b^{S}}<0$, as can be seen from the FOC of households with regard to S-bank debt

$$
q^{S}=\underbrace{Q \Lambda_{S}\left(\frac{H}{N^{S}}\right)^{1-\alpha}}_{: \equiv M R S_{S}}+\beta\left[1-F_{\rho}^{S}+F_{\rho}^{S}\left(\pi_{B}+\left(1-\pi_{B}\right) r^{S}\right)\right]
$$


When choosing leverage, we assume that shadow banks take into account that their default risk is priced. In this sense, each shadow bank acts as a monopolist for its own debt. But it does not internalize how its leverage choice and default risk affects the value of liquidity services for households. This is intuitive, as shadow bank bond prices are sensitive to the specific default risk of the issuer. But they also move with changes in aggregate liquidity conditions, which are caused by actions of all shadow banks, but not by any individual bank. Thus, it is best to think of the changes in the value of aggregate liquidity services as an externality arising in general equilibrium.

The following proposition states the resulting endogenous leverage choice of S-banks:

Proposition. Leverage $L^{S}$ of $S$-banks is

$$
L^{S}=\frac{\frac{1}{\beta} M R S_{S}+F_{\rho}^{S} \pi_{B}}{\xi_{S}\left(1-\pi_{B}\right) f^{S}}-\frac{\left(1-\xi_{S}\right)}{\xi_{S}} \delta_{S} .
$$

Proposition 24 can be proven by combining households' FOC with regard to S-bank debt (equation 23) with shadow banks' FOC (equation 22) and substituting for $\frac{\partial q^{S}\left(b^{S}\right)}{\partial b^{S}}$ using the steady state version of equation 18. The expression shows that shadow bank leverage rises with the marginal benefit of shadow bank liquidity $\left(M R S_{S}\right)$ and the bailout probability. Conversely, the bankruptcy cost $\xi_{S}$ and the default penalty $\delta_{S}$ reduce leverage.

Size of the Banking Sectors \& Procyclical Shadow Banking Activity The optimal choice of capital share purchases $K^{j}$ for each bank type $j=C, S$ imply

$$
v^{j}(Z)=0,
$$

for any $K^{j}>0$. 
We can think of condition (25) as determining the relative size of the $j$-bank sector:

$$
\begin{aligned}
p-\left(q^{C}-\kappa\right) b^{C} & =\beta\left(Z+\left(1-\delta_{K}\right) p\right) \mathcal{F}^{\mathcal{C}}, \\
p-q^{S} b^{S} & =\beta\left(Z+\left(1-\delta_{K}\right) p\right) \mathcal{F}^{\mathcal{S}} .
\end{aligned}
$$

For any reasonable parameter combinations, the above equilibrium choices of capital stock purchases and leverage for both types of banks imply that $C$-banks have a dominant position in the capital share $\left(\frac{K^{C}}{K}>\frac{K^{S}}{K}\right)$. The intuitive reason for this equilibrium outcome is as follows.

First, C-banks' debt is insured and therefore C-banks do not internalize the effect of their leverage choice on the price of their debt. Since the marginal liquidity benefit is always positive, C-banks always exhaust their leverage constraint. S-banks, however, do internalize the increase in their default risk. Hence, if C-banks and S-banks are fundamentally equally risky, S-banks choose lower leverage ${ }^{15}$. Required initial equity for C-banks is $p-q^{C} b^{C}$. Leverage $L^{C}$ is a constant and higher than that of S-banks if $\theta$ is sufficiently small. In equilibrium, the bond price $q^{C}$ adjusts in order for marginal dividend to equal the marginal cost of equity. For reasonable parameter combinations, this in turn means that the marginal benefit of C-bank debt to households must be lower than that of S-bank debt. If debt is further sufficiently substitutable, this means that C-banks must hold a greater share of the intermediated asset in equilibrium. ${ }^{16}$

The exact split between both types of banks depends on several parameters, particularly the elasticity of substitution between both kinds of liquidity $\alpha$.

\footnotetext{
${ }^{15}$ This statement of course depends on the parameters of the model, in particular the value of $\theta$, i.e. the tightness of C-banks' leverage constraint. For any values close to the capital requirements of commercial banks, we found this statement to be true.

${ }^{16}$ Even for equal shares of asset holdings $\left(\frac{K^{C}}{K}=\frac{K^{S}}{K}\right)$, C-banks will produce $N^{C}>N^{S}$ due to their higher leverage. If both types of debt are close to being complements, the higher leverage of C-banks by itself is sufficient to create the lower marginal benefit. Thus the C-bank share is increasing in the elasticity parameter $\alpha$.
} 
The relative size of both banking sectors is determined in equilibrium by the marginal benefit of opening each bank in this period and receiving dividends next period. Mathematically, this means that the holdings of the intermediated capital stock by both types of banks, $K^{C}$ and $K^{S}$, and thus the relative size of both banking sectors, are jointly determined by the FOCs (26) and (27).
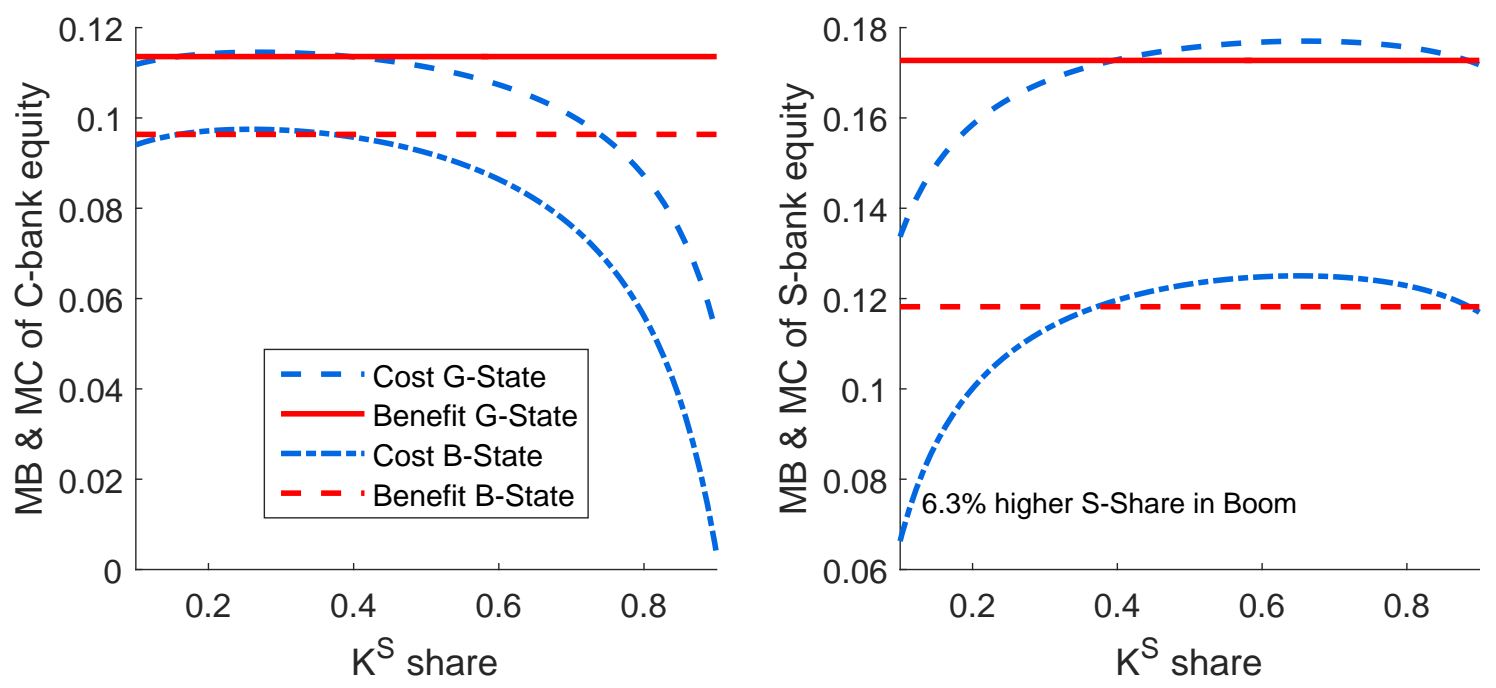

Figure 2: Equilibrium Determination of $K^{C}$ and $K^{S}$ for $\alpha=0.56$

Left-hand side (marginal cost, i.e. required equity, blue line) and right-hand side (marginal benefit, red line) of banks' first-order condition for asset holdings $\left(K^{j}\right)$, while imposing market clearing $K=K^{C}+K^{S}$ and holding fixed all other variables.

Figure (2) shows the LHS and RHS of both equations graphically for the calibrated model, depending on the current state of the economy. ${ }^{17}$ We first numerically compute the equilibrium values of all variables. Then we vary the share of S-banks and C-banks, $K^{S}$ and $K^{C}$, while holding all other variables fixed (and imposing market clearing $K^{S}+K^{C}=K$ ). The blue lines (i.e. the equity funding costs) trace the value of the LHS of the first-order conditions (26) and (27) as we vary the shares, $p-q^{j} b^{j}$, for $j=C, S$, respectively. Holding

\footnotetext{
${ }^{17}$ In the deterministic model, the notion of state is not well defined. What we mean here by state is the endowment value for which we solve the deterministic model. In the bad "state"', banking sector profitability $Z$ and household endowment $Y$ are only $80 \%$ of the value in the good "state"'.
} 
constant $p$ and $b^{j}$, the only source of variation is through the bond price $q^{j}$. Since total debt issued by each type is given by asset share times leverage per unit of assets, $N^{j}=b^{j} K^{j}$, the marginal benefit of deposits of each type changes as we vary the asset shares, as can be seen from the pricing equations for the $q^{j},(21)$ and (23). In particular, as we increase the share of type $j$ holding total provided liquidity constant, the marginal liquidity benefit of type $j$ 's deposits will decline (for any $\alpha<1$ ), and therefore type $j$ 's bond price will also decline. This means that the equity required to purchase the bank's initial asset position becomes larger for the same face amount of debt issued.

An opposing effect is that, as long as liquidity services provided by both types of debt are imperfect substitutes, the marginal benefit derived from each type's debt is also affected by the composition of the total debt. When we increase the share of C-banks, we decrease the share of S-banks due to market clearing, holding constant the aggregate capital stock. Consequently the composition of liquidity services becomes more unequal and the amount of services derived from total debt issued by both banks declines, which leads to a general increase in the marginal benefit of both kinds of liquidity. Both effects, the pure effect of an increase in the $K^{C}$ share and the equilibrium effect through the implied decrease in the $K^{S}$ share can be seen in left panel of (2). Lowering the $K^{S}$ share from 0.8 to about 0.3 (= raising the $K^{C}$ share from 0.2 to 0.7 ) causes a decrease in the marginal benefit of C-bank debt to households, which in turn lowers the bond price $q^{C}$ and therefore raises the required initial equity of C-banks (the blue line in the graph). By lowering the S-bank share any further, the composition of debt becomes so unequal that the marginal benefit of any liquidity rises again, causing both bond prices (also $q^{C}$ ) to increase again. Hence the required equity of C-banks bends backwards, yielding the overall non-monotonic shape.

The effect on the RHS of equation (27) is depicted by the red lines and quantitatively smaller. The discounted expected dividend (per unit of assets) is not affected in the steady 
state by a variation in the share of $K^{S}$. In the dynamic model, it will work through the households' discount factor which depends on consumption $C$.

The overall take-away from the left panel of figure (2) is that the FOC of C-banks is satisfied at two points, the actual equilibrium share of $\frac{K^{C}}{K}=0.60\left(\frac{K^{S}}{K}=0.40\right)$ and an even higher share of $\frac{K^{C}}{K}>0.80$. The unique equilibrium split is then determined by the FOC of S-banks, depicted in the right panel of the figure. It also has two potential equilibria, but only of which satisfies C-banks FOCs. The forces determining the shapes of required equity (blue line) and expected dividend (red line) are the same as for C-banks. The unique intersection with the expected discounted dividend of S-banks that satisfies the FOC of C-banks is at $\frac{K^{S}}{K}=0.4$.

The share of shadow banking activity also depends on the economic state as figure (2) shows. In a boom (solid red line and dashed dashed blue line), shadow banks can issue debt at a higher price because they are less likely to fail next period. Moreover, because the default probability is lower, the expected dividend payment is larger. This means that shadow banking activity is pro-cyclical.

Welfare-maximizing Capital Requirement The deterministic model delivers a qualitative welfare result with respect to the optimal capital requirement for C-banks, $\theta$. The general conditions for this result to obtain are

C1. C-banks are sufficiently risky such that there exists a range for low values of $\theta$ for which some C-banks default, i.e. $F^{C}<1$.

C2. S-banks are at least as risky as C-banks; in other words, the standard deviation of their idiosyncratic shocks $\sigma^{S}$ is at least as large as that of C-banks.

C3. Households derive a strictly positive utility benefit from liquidity services $(\psi>0)$, and 
the liquidity services provided by C-banks are at least as good as those of S-banks.

Under these fairly general conditions there exists a trade-off in the model that leads to a unique utility maximum in $\theta$. Figure (3) illustrates the trade-off for two different values of $\pi_{B}$. In both instances increasing the capital requirement leads to an increase in consumption (top right graph), as fewer C-banks default due to lower leverage and hence bankruptcy losses become smaller. At the same time, decreasing C-bank leverage through tighter capital requirements lowers the amount of liquidity services provided to households (bottom left), as a greater share of the intermediated asset is shifted to S-banks (top left). Since total utility is a weighted sum of both components, there exists a unique welfare maximum that trades off the reduction in liquidity provision against the reduction in deadweight losses due to fewer defaults of C-banks. 

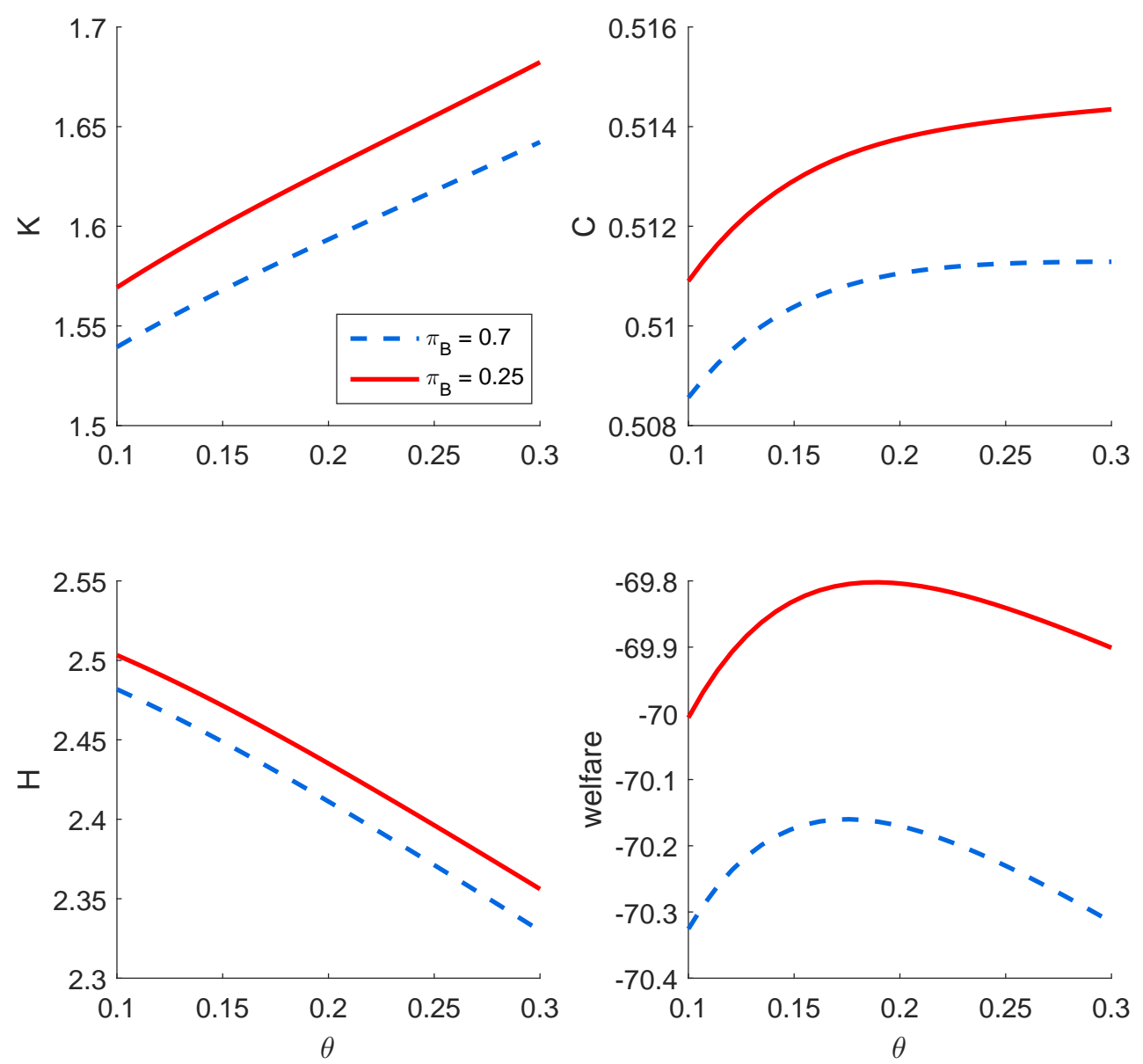

Figure 3: Comparative Statics in Capital Requirement $\theta$

Top left: share of S-banks, top right: consumption, bottom left: utility from liquidity services, bottom right: total household utility.

Welfare is higher when the government is less likely to bail out shadow banking liabilities. This is intuitive as shadow banks endogenously choose to be safer when they can expect less government support. Moreover, the optimal capital requirement is higher in the low $\pi_{B}$ economy. The intuition for this effect is the following. Since higher capital requirements shift activity towards the shadow banking system, a cost of a higher capital requirement is the deadweight loss caused by a higher shadow banking share. At low values of $\pi_{B}$, shadow banks are relatively safe, causing little deadweight losses even when the S-bank share is increased. 
The higher $\pi_{B}$, the higher the deadweight losses inflicted by a larger shadow banking sector.

\section{Results}

We are now ready to study the properties of the model and its implication for optimal regulation.

\subsection{Parametrization}

We match the model to quarterly data. We use data from the Flow of Funds, ${ }^{18}$ Compustat, FRED, NIPA, and focus on the period between 1999 (after the passage of the Gramm-LeachBliley Act that revoked parts of the Glass-Steagall Act) until the last quarter of 2014.

We choose depository institutions as data counterparts for $C$-banks and shadow bank institutions as data counterparts for $S$-banks where we define shadow banks in the flow of funds data as security broker and dealer, finance companies, GSEs, and asset-backed security issuers when using sector definitions from the Flow of Fund. The Compustat based definition of shadow banks mirrors that definition. ${ }^{19}$

The stochastic process for the Y-tree (not intermediated by banks) is a AR(1) in logs

$$
\log \left(Y_{t+1}\right)=\left(1-\rho_{Y}\right) \log \left(\mu^{Y}\right)+\rho_{Y} \log \left(Y_{t}\right)+\epsilon_{t+1}^{Y},
$$

where $\epsilon_{t}^{Y}$ is i.i.d. with mean zero and volatility $\sigma^{Y}$. To capture the correlation of asset payoffs with fundamental income shocks, we model the payoff of the intermediated asset as

$$
Z_{t}=\phi^{Z} Y_{t} \exp \left(\epsilon_{t}^{Z}\right),
$$

\footnotetext{
${ }^{18}$ The Flow of Funds tables are organized according to institutions and instruments. We focus on the balance sheet information on institutions. This is important, as we want to take into account all bank and shadow-bank positions when we quantify the model.

${ }^{19}$ We include financial institutions with the following SIC code 6111-6299, 6799, 6722, 6726, excluding 6200, 6282, 6022 .
} 
where $\epsilon_{t}^{Z}$ is i.i.d. with mean zero and volatility $\sigma^{Z}$, independent of $\epsilon_{t}^{Y}$. This structure of the shocks implies that $Z_{t}$ inherits all stochastic properties of aggregate income $Y_{t}$, and is subject to an additional temporary shock that reflects risks specific to intermediated assets, such as credit risk.

For the investment technology, we choose a standard quadratic adjustment $\operatorname{cost}^{20}$

$$
\Phi\left(I_{t}\right)=\frac{\phi}{2} I_{t}^{2}
$$

Our choice of parameters is listed in table 1. The table groups parameters according to the method through which they have been choosen: normalization, directly set to a data counterpart, matching unconditional first moments, and matching unconditional second moments.

In order to parametrize the shock processes we use Flow of Funds tables S.1 and S.6 to obtain a time series for the value added of the financial sector and GDP which we deflate and express in GDP per capita using NIPA data. Normalizing the mean of per capita real GDP growth process to $\mu^{Y}=0.5$ we can derive $\sigma^{Y}$ and $\rho_{Y}$ from the observed volatility and autocorrelation. Similarly, using the per capital real financial sector value added time series (and its observed volatility), we find a value for the scale of the intermediated asset payoff $\phi^{Z}$ and $\sigma^{Z}$.

The fraction of households that defaults each period is $\varrho_{t}$ and follows a Markov-process that takes two values: zero in the first state (no run) and 0.3 in the second state (run state), i.e. $30 \%$ of depositors run on shadow banks. In the simulation, bank runs occur only in bad economic states. We interpret the run on shadow banks in the model as akin to a run on ABCP programs and repurchase agreements (e.g. Covitz, Liang, and Suarez (2013) and Gorton and Metrick (2012)). Commercial paper and repurchase agreements are common

\footnotetext{
${ }^{20}$ This implies the usual first-order condition for investment $I_{t}=\frac{p_{t}-1}{\phi}$.
} 
funding sources for dealer banks and finance companies. We pick a household run fraction of $30 \%$ based on Covitz, Liang, and Suarez (2013)'s observation that 30\% of ABCP programs experienced a run at the beginning of the crisis. We set the transition probability between bank run and non-bank run states to target an unconditional probability of a bank-run of $3 \%$, i.e. there is one bank run every 33 years, roughly consistent with the past 100 years of U.S. banking history.

We set $\kappa$, the deposit insurance fee to 0.0006168 . This is in the range of quarterly FDIC assessment rates.

The key parameters for our quantitative results have been choosen to match unconditional first and second moments. The size of the capital stock is mainly affected by $\beta$. This is intuitive because $\beta$ determines the saving propensity of agents. The larger $\beta$, the higher are the incentives, leading to a larger capital stock, i.e. financial assets in this economy, relative to GDP. We target thus the ratio of financial assets to GDP using Flow of Funds data.

The value of liquidity provision is mainly determined by three key preference parameters: the elasticity of substitution between shadow bank and commercial bank liquidity services ( $\alpha=1-1$ /elasticity), the weight on liquidity services $\psi$, and the parameter $\nu$ that governs the sensitivity of the liquidity quality of shadow banking debt. To fix ideas, it is useful to interpret commercial bank debt as deposits and shadow bank debt as money market mutual fund shares.

We choose these three parameters as follows. Deposits and money market mutual fund shares are similar in terms of risk and liquidity and hence produce liquidity services but they are not perfectly substitutable. For example money market mutual fund shares cannot be used directly for transactions in contrast to most deposits. In the model the degree of substitutability between these two securities is governed by $\alpha$. Both bank types differ mainly 
in terms of their differences in liquidity service, thus $\alpha$ helps to pin down the size of the size of commercial banks relative to shadow banks. We target Gallin (2013)'s estimate of the $33 \%$ share of shadow banks in total financial intermediation. ${ }^{21}$

The utility weight on liquidity services $\psi$ affects how valuable liquidity services are relative to consumption. We target Krishnamurthy and Vissing-Jorgensen (2012) estimate of government debt liquidity services as a proxy for the liquidity of commercial banks $\psi$. We choose $n u$, the shadow bank debt liquidity quality parameter, in order to match the rate on shadow banking debt. Since many non-depository institutions rely substantially on the commercial paper market we proxy the rate on shadow bank debt by the commercial paper rate on financial institutions (3-month financial commercial paper rate from FRED).

We choose the bailout probability $\pi^{B}$ to match the market value leverage of shadow banks in Compustat. That is, we compute the value weighted leverage of publicly traded shadow banks $^{22}$ as debt over assets weighted by the relative market value of each institution and average across time and banks. The result is a value-weighted leverage ratio of $94 \%$. The volatility of the idiosyncratic valuations shocks $\sigma^{S}$ and $\sigma^{C}$ proxy the relative riskiness of investment opportunities for banks. As a target for these two parameter, we choose the cross-sectional volatility of Tobin's q (market value of assets relative to book value) for depository institutions and shadow banks in Compustat.

The utility penality parmaeters $\delta^{S}$ and $\delta^{C}$ for bank managers determines the default threshold level of bank leverage. We choose $\delta^{C}$ to target a $1 \%$ annual default rate of commercial banks. The choice of the data counterpart is not trivial. FDIC data suggests a

\footnotetext{
${ }^{21}$ More precisely, Gallin (2013) used data from the Flow of Funds to carefully trace back how much shadow banking sector funding the real economy received. Since many shadow banks fund each other and not necessarily real activity the actual share of shadow activity is much lower (around 33\%) than what one would expect given the total asset size of the financial sector.

${ }^{22}$ We define shadow banks as all institutions with SIC codes 6111-6299, 6799, 6722, 6726, excluding SIC codes $6200,6282,6022,6199$.
} 
higher rate (4\%), mainly driven by smaller less important banks, while Moody reports typically suggest a lower rate $\left(0.6 \%\right.$ for the entire banking sector). We choose the parameter $\delta^{S}$ to target the spread between the non-jumbo 3-month deposit rate and the 3-month financial commercial paper rate from FRED.

The bankruptcy cost parameters $\xi_{S}$ and $\xi_{C}$ are relevant for the deadweight loss from bank default. We choose a bankruptcy costs of $37 \%$ to target a recovery rate of $63 \%$ from Moody reports on financial sector bond recoveries. ${ }^{23}$

\footnotetext{
${ }^{23}$ We use Moody's 1984-2004 . Exhibit 9 in the report presents the recovery rates of defaulted bond for financial institutions. We use the mean for financial institutions over all bonds and preferred stocks.
} 
Table 1: Parametrization

\begin{tabular}{|c|c|c|c|c|c|}
\hline \multicolumn{3}{|c|}{ Values } & Target & Data & Model \\
\hline$\mu_{Y}$ & \multicolumn{2}{|l|}{0.5} & normalization & & \\
\hline$\mu_{\rho}^{C}$ & \multicolumn{2}{|l|}{1} & normalization & & \\
\hline$\mu_{\rho}^{S}$ & \multicolumn{2}{|l|}{1} & normalization & & \\
\hline \multicolumn{6}{|c|}{ set directly } \\
\hline$\phi^{Z}$ & 0.075 & & Val add. FinSec/GDP & & \\
\hline$\delta_{K}$ & 0.025 & & set to imply $10 \%$ annual depreciation & & \\
\hline$\gamma$ & 2 & & B. H. & & \\
\hline$\theta$ & 0.1 & & policy parameter & & \\
\hline$\kappa$ & 0.000617 & & insurance fee & & \\
\hline$\sigma^{Y}$ & 0.00716 & & vol of GDP net of financial sector & & \\
\hline$\delta_{Y}$ & 0.268 & & $\mathrm{AC}$ of net of fin GDP & & \\
\hline$\mu^{Z}$ & 0.04 & & $\mu^{Y} \times \phi^{Z}$ & & \\
\hline \multirow[t]{2}{*}{$\sigma^{Z}$} & 0.05646 & & vol of fin val added & & \\
\hline & & & run & & \\
\hline$\underline{\delta}_{K}$ & 0.05 & & haircut (discount) $x_{t}$ & $75 \%$ & $77 \%$ \\
\hline & 0 & 0.3 & fraction of households run & Covitz et & al 2013 \\
\hline \multirow{3}{*}{$\begin{array}{r}\text { Prob }_{\varrho} \\
\underline{Z}\end{array}$} & {$[0.93 ; 0.07$} & $0.4 ; 0.6]$ & uncond. run prob. & $3 \%$ & $3 \%$ \\
\hline & 0.9 & & $\mathrm{Z}$ in run state & & \\
\hline & & & calibrated & & \\
\hline$\beta$ & 0.9797 & & fin assets relative to GDP & 3.33 & 3.17 \\
\hline$\alpha$ & 0.66 & & shadow banking share Gallin & $33 \%$ & $33 \%$ \\
\hline$\psi$ & 0.037 & & match liquidity premium KV2012 & $73 \mathrm{bp}$ & $127 \mathrm{bp}$ \\
\hline$\nu$ & 85 & & match rate on AA Financial CP & $0.65 \%$ & $0.90 \%$ \\
\hline$\delta_{S}$ & 0.49 & & S-Cbank debt spread & $0.60 \%$ & $0.10 \%$ \\
\hline$\delta_{C}$ & 0.125 & & default rate $\mathrm{C}$ FDIC quarterly & $0.25 \%$ & $0.22 \%$ \\
\hline$\xi_{C}$ & 0.5565 & & recovery rate Moody's & $37 \%$ & $37 \%$ \\
\hline$\xi_{S}$ & 0.14 & & recovery rate Moody's & $37 \%$ & $37 \%$ \\
\hline \multirow[t]{2}{*}{$\pi_{B}$} & 0.55 & & Sbank leverage Compustat & $94 \%$ & $94 \%$ \\
\hline & & & 2nd moments & & \\
\hline$\sigma_{\rho^{C}}$ & 0.09 & & $\operatorname{vol}(\mathrm{mkt}$ assets/assets) & 0.07 & 0.10 \\
\hline$\sigma_{\rho^{S}}$ & 0.25 & & $\operatorname{vol}(\mathrm{mkt}$ assets/assets) & 0.49 & 0.40 \\
\hline$\phi$ & 2 & & vol(financial sector asset growth) & 0.021 & 0.007 \\
\hline
\end{tabular}




\subsection{Solution Method and Aggregate State Variables}

We solve the dynamic model using nonlinear methods. To do so, we write the equilibrium of the economy as a system of nonlinear functional equations of the state variables, with the unknown functions being the agents' choices, the asset prices, and the Lagrange multiplier on the $C$-bank's leverage constraint. We parametrize these functions using splines and iterate on the system until convergence. We check the relative Euler equation errors at the solution we obtain to make sure the unknown functions are well approximated. We then simulate the model for many periods and compute moments of the simulated series.

The model has three exogenous state variables, the stochastic endowment $Y_{t}$, productivity $Z_{t}$, and the run shock $\varrho_{t}$. These shocks are joint discretized as a first-order Markov chain with three nodes for $Y_{t}$ and three nodes for $Z_{t}$. We assume that runs only occur in low productivity states, yielding a total of 12 different discrete states.

The model further has four endogenous aggregate state variables. These are (1) the aggregate capital stock $K_{t}=K_{t}^{S}+K_{t}^{C}$, the debt outstanding relative to bank capital stock by each type of bank at the beginning of the period (2) $b_{t}^{S}$ and (3) $b_{t}^{C}$, and (4) the share of

capital held by one type of bank, e.g. $\frac{K_{t}^{S}}{K_{t}}$. Inspecting the optimization problem for S-banks and C-banks, it is obvious that the value functions $v^{S}$ and $v^{C}$ do not depend on past portfolio choices of the bank. Why then are the debt of both types of banks and the share of capital held by each type aggregate state variables? The reason is that the level of debt of each type determines household utility from liquidity, and these quantities are therefore aggregate state variables for households. Furthermore, in combination which each type's capital share, the outstanding debt determines beginning-of-period leverage $L_{t}^{j}$, which in turn determines household wealth and consumption (alternatively, we could choose household wealth as an additional state variable directly). 


\subsection{Benchmark Economy}

Table (2) reports means, standard deviations, business cycle correlations (correlations with $\mathrm{Y}$ ), correlations with $\mathrm{Z}$ and $\varrho$, as well as autocorrelations, for the benchmark economy with $\theta=10 \%$.

The price for the intermediated asset moves together with $Y$ and $Z$. Good times make intermediation more valuable. Co-movements with $Z$ are not surprising, while co-movements with $Y$ are induced by the complementarity between consumption and liquidity on the demand side and the loosening of the leverage constraint (regulatory and endogenous respectively) on the supply side. The deposit rates for commercial and shadow banks are countercyclical in the $Z$ shock. Time variation in the interest rate is caused by (i) the standard intertemporal consumption smoothing motive, and (ii) fluctuations in the marginal benefit of liquidity. While the first source of variation induces the usual procyclical movement with GDP shocks, the second source causes interest rates to be very countercyclical in the $Z$ payoff. The return on equity for both types of banks is of similar magnitude - the expected excess return for both types is around 1.5 percentage points. Both bank's equity returns contain countercyclical risk premia.

The liquidity quality factor $\Lambda^{S}$ is decisively procyclical as shadow banks' survive with higher likelihood in good times. During run states liquidity quality deterioriates. The convenience yields measure the marginal benefit of liquidity and are components of the bond prices $q^{C}$ and $q^{S}$. These convenience yields are quantitatively large given our calibration. In states with low payoffs of the $Z$ asset, banks tighten their supply of debt that yields liquidity services, leading to a high marginal benefit and high convenience yields during those times.

The model captures counter-cyclical market value leverage for both banks. The balance sheet of commercial banks moves with $Z$, a reflection of a relaxed leverage constraint in good 
Table 2: This table presents moments of key variables of the benchmark economy $(\theta=10 \%)$.

\begin{tabular}{|c|c|c|c|c|c|c|}
\hline & Mean & SD & Corr Y & Corr Z & Corr $\varrho$ & $\mathrm{AC}$ \\
\hline & \multicolumn{6}{|c|}{ Prices } \\
\hline Capital Price & 1.082 & 0.015 & 0.705 & 0.788 & -0.153 & 0.138 \\
\hline Deposit Rate $\mathrm{S}$ & 0.009 & 0.012 & -0.595 & -0.869 & 0.154 & 0.098 \\
\hline Deposit Rate C & 0.008 & 0.012 & -0.591 & -0.871 & 0.178 & 0.097 \\
\hline EER Equity $\mathrm{S}$ & 0.014 & 0.001 & -0.612 & -0.800 & 0.072 & 0.220 \\
\hline \multirow[t]{2}{*}{ EER Equity $\mathrm{C}$} & 0.015 & 0.001 & -0.594 & -0.788 & 0.110 & 0.217 \\
\hline & \multicolumn{6}{|c|}{ Liquidity } \\
\hline$\Lambda^{S}$ & 0.808 & 0.058 & 0.547 & 0.873 & -0.229 & 0.041 \\
\hline Convenience Yield S & 0.013 & 0.000 & -0.267 & -0.380 & 0.699 & 0.525 \\
\hline \multirow[t]{2}{*}{ Convenience Yield C } & 0.013 & 0.000 & -0.490 & -0.517 & -0.055 & 0.682 \\
\hline & \multicolumn{6}{|c|}{ Quantities } \\
\hline Capital Stock & 1.603 & 0.037 & 0.069 & 0.002 & 0.019 & 0.977 \\
\hline Debt $S$ & 0.535 & 0.083 & 0.154 & 0.014 & -0.070 & 0.114 \\
\hline Debt C & 1.031 & 0.055 & -0.097 & -0.011 & 0.103 & 0.090 \\
\hline Capital Share S & 0.329 & 0.049 & 0.148 & 0.014 & -0.077 & 0.058 \\
\hline Asset Value S & 0.571 & 0.090 & 0.210 & 0.081 & -0.082 & 0.195 \\
\hline Asset Value C & 1.163 & 0.082 & 0.005 & 0.136 & 0.055 & -0.100 \\
\hline Leverage $\mathrm{S}$ & 0.937 & 0.012 & -0.676 & -0.794 & 0.151 & 0.057 \\
\hline Leverage C & 0.88 & 0.020 & -0.245 & -0.451 & 0.072 & -0.376 \\
\hline \multirow[t]{2}{*}{ Early Liquidation Share } & 0.010 & 0.053 & 0.012 & -0.215 & 1.000 & 0.159 \\
\hline & \multicolumn{6}{|c|}{ Bankruptcy Losses } \\
\hline DWL S & $0.02 \%$ & $0.06 \%$ & -0.008 & -0.246 & 0.976 & 0.081 \\
\hline DWL C & $0.10 \%$ & $0.09 \%$ & -0.244 & -0.527 & 0.112 & -0.310 \\
\hline Default Rate S & $0.25 \%$ & $0.09 \%$ & -0.548 & -0.865 & 0.233 & 0.039 \\
\hline \multirow[t]{2}{*}{ Default Rate C } & $0.22 \%$ & $0.21 \%$ & -0.233 & -0.510 & 0.103 & -0.311 \\
\hline & \multicolumn{6}{|c|}{ Utility } \\
\hline Liquidi & 1.957 & 0.123 & 0.571 & 0.790 & -0.205 & 0.271 \\
\hline Consumption & 0.518 & 0.004 & 0.685 & 0.697 & -0.124 & 0.361 \\
\hline Aggregate Welfare & -83.815 & 0.077 & 0.393 & 0.303 & -0.058 & 0.896 \\
\hline
\end{tabular}


states. $^{24}$

Overall, the financial sector is more stable in good economic times as default risk is lower. On the flipside, deadweight losses due to intermediary bankruptcy are higher in bad states of the economy, in particular those bad states that affect the financial sector the most (low $Z$ payoffs).

\subsection{Shadow Bank Runs}

Shadow banks are fragile in our model because they experience occasional large deposit outflows that force them to incur fire-sale losses on their assets. These infrequent episodes of shadow bank fragility quantitatively capture a possible downside of too much shadow banking activity that is absent in the deterministic version of the model.

Runs on the deposits of shadow banks $(\varrho>0)$ cause shadow banks to shrink their balance sheets. They lose capital share and issue less debt. At the same time, their default rate spikes and the quality of the liquidity services they provide $\left(\Lambda^{S}\right)$ drops. Interestingly, shadow bank deposit rates fall during these periods. Due to the high bailout probability (70\%), interest rates only reflect credit risk partially, but the drop in shadow bank liquidity raises its marginal benefit. This quantity effect dominates the compensation for increased bankruptcies.

In figure 4 and figure 5 we compare the impulse response functions to a low realization of $Z$ (low productivity in the financial sector) (blue line), to one with a low $Z$ realization and a run on the shadow banking sector (red line). The benchmark unconditional economy is in black. A run on shadow bank deposits leads to a higher default rate in the shadow banking sector (figure 4 top left), causing shadow banking debt to be less liquid (figure 4 bottom left), and a lower overall production of liquidity services in this economy (figure 4 bottom right).

\footnotetext{
${ }^{24}$ We designed the leverage constraint to reflect a Basel II type of capital requirement that has been criticized for its procyclical effects.
} 
The default rate in the commercial banking sector is higher during a crisis without a run, while the opposite is true for shadow banks.

The aggregate consequences of a crisis with a run on the shadow banking sector is significantly worse. Even though the difference in output is negligible, the fall in the aggregate capital stock, investment and consumption is more dramatic. The larger negative response in consumption has to do with a higher savings need in order to make up for the fall in investment and the capital stock (figure 5). Since investment is subject to adjustment costs, the large initial impact in the run-crisis has persistent effects over many years ( $\mathrm{x}$-axis is in quarters). 

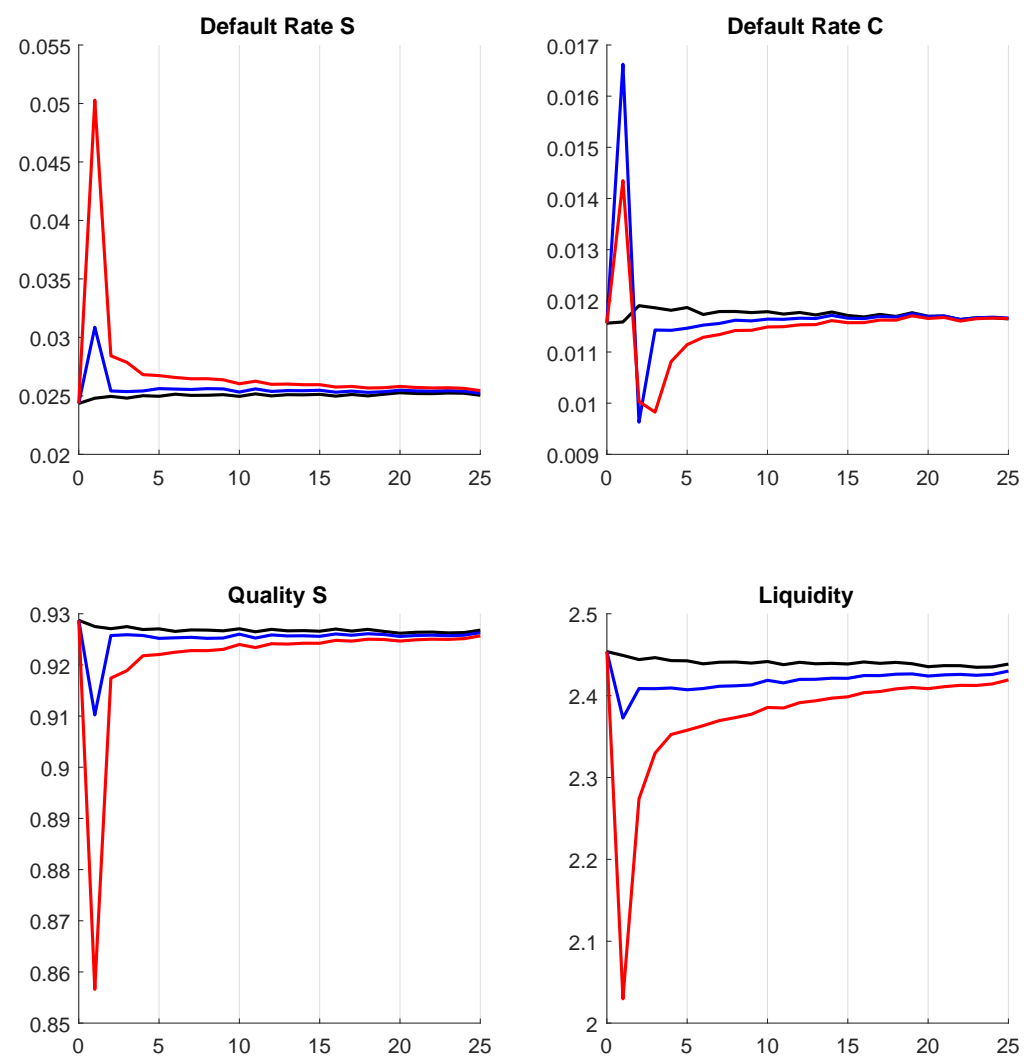

Figure 4: Dynamic Response to Low $Z$

Graphs show the dynamic responses of model variables to a regular low payoff shock for the intermediated asset (blue line) and a low payoff shock combined with a run on shadow banks (red line), compared to the unconditional evolution of all variables (black line). Responses are the mean paths of 1000 model simulations for 25 periods. 

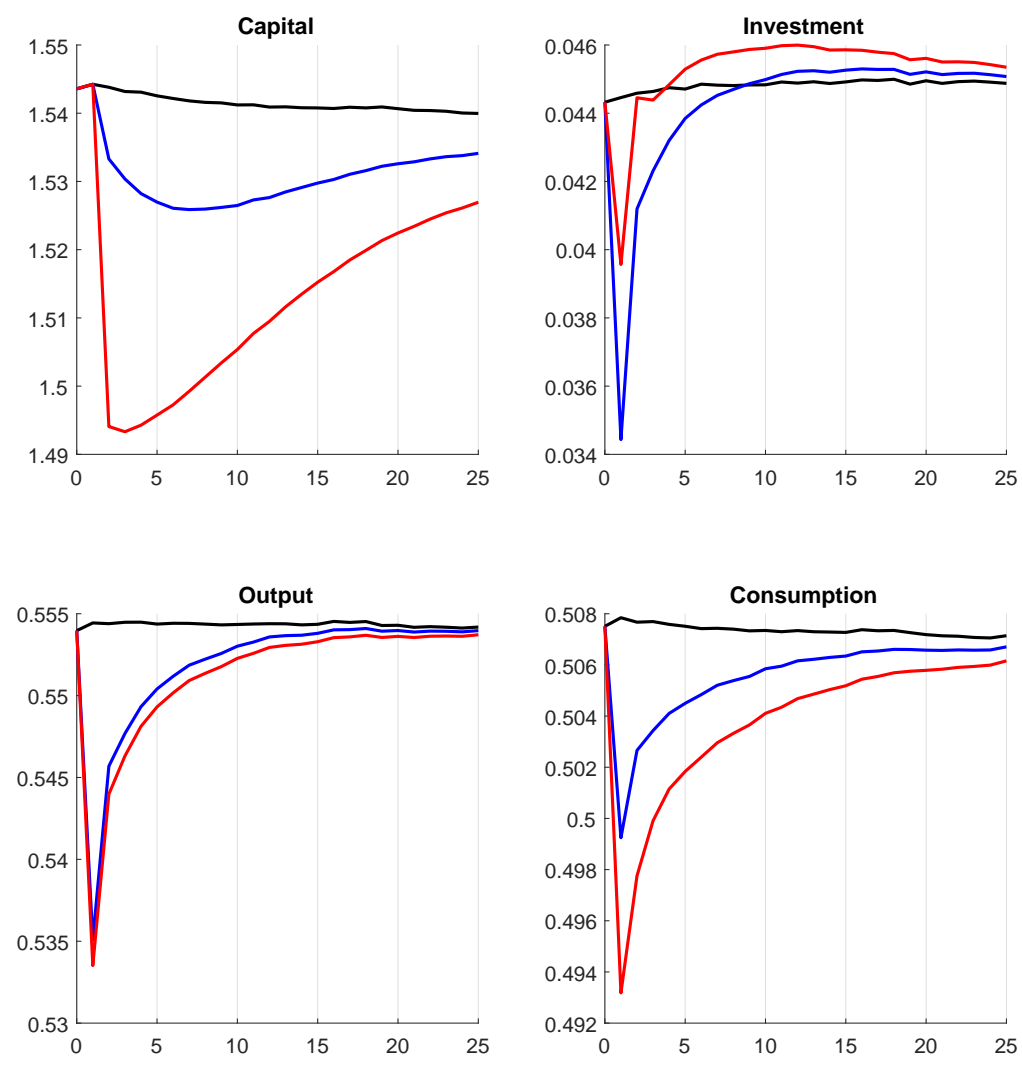

Figure 5: Dynamic Response to Low $Z$

Graphs show the dynamic responses of model variables to a regular low payoff shock for the intermediated asset (blue line) and a low payoff shock combined with a run on shadow banks (red line), compared to the unconditional evolution of all variables (black line). Responses are the mean paths of 1000 model simulations for 25 periods.

\subsection{Welfare}

There is a unique maximum in aggregate welfare from increasing the capital requirement $\theta$. We consider two cases for the effect of a change in the capital requirement. First, we compare economies with different $\theta$ for the benchmark calibration with a bailout probability of $\pi^{B}=55 \%$. In this case, a capital requirement around 15 percent is welfare maximizing. The main forces leading to this result are the same as we already discussed for the steady 
state. Increasing $\theta$ makes the debt of commercial banks safer, thus reducing bankruptcy losses and increasing aggregate consumption. At the same time, a higher level of $\theta$ restricts the amount of liabilities and thus liquidity commercial banks can produce for each unit of assets.

We also consider the benefit of an increase in $\theta$ for a lower bailout probability of $\pi^{B}=15 \%$. In this economy, the baseline leverage and failure rate of shadow banks is lower, which implies a larger gain from increasing the capital requirement. As in the deterministic economy (see figure 3), a lower bailout probability increases shadow banks' incentives to take into account the risks they face when choosing leverage.

Baseline $\left(\pi^{B}=\mathbf{5 5 \%}\right)$ The middle panel of table 3 shows that an increase in the capital requirement shifts a greater fraction of the intermediated asset to shadow banks. Restricting the liquidity production by commercial banks increases the marginal benefit of liquidity to households. Shadow banks take advantage of the lower funding costs by holding more of the intermediated assets.

Shadow banks do not increase their leverage in response to the scaling back of commercial banks. Rather, they keep their leverage roughly constant. Overall liquidity production falls monotonically as long as the liquidity produced by $S$-banks is less valuable to households than that produced by $C$-banks (which is the case as long as $\Lambda^{S}<1$ ).

Commercial banks become safer as the capital requirement is raised, leading to overall fewer deadweight losses and higher consumption. However, in the dynamic model increasing the requirement leads to greater liquidity volatility. For the risk-averse household, this leads to a small offsetting effect, making the overall welfare gain smaller than in the steady state. The result is that total welfare already becomes decreasing in the capital requirement before all bankruptcy losses are eliminated; in other words, our calibrated model says that it is not 
Table 3: Model Moments for Different Capital Requirements

\begin{tabular}{|c|c|c|c|c|c|c|}
\hline & \multicolumn{2}{|c|}{$10 \%$} & \multicolumn{2}{|c|}{$15 \%$} & \multicolumn{2}{|c|}{$20 \%$} \\
\hline & mean & stdev & mean & stdev & mean & stdev \\
\hline & \multicolumn{6}{|c|}{ Prices } \\
\hline Capital Price & 1.082 & 0.015 & 1.082 & 0.015 & 1.081 & 0.015 \\
\hline Deposit Rate S & 0.009 & 0.012 & 0.009 & 0.012 & 0.009 & 0.012 \\
\hline Deposit Rate C & 0.008 & 0.012 & 0.007 & 0.012 & 0.006 & 0.012 \\
\hline EER Equity S & 0.014 & 0.001 & 0.015 & 0.001 & 0.016 & 0.001 \\
\hline \multirow[t]{2}{*}{ EER Equity C } & 0.015 & 0.001 & 0.015 & 0.001 & 0.016 & 0.001 \\
\hline & \multicolumn{6}{|c|}{ Liquidity } \\
\hline$\Lambda^{S}$ & 0.808 & 0.058 & 0.811 & 0.057 & 0.808 & 0.059 \\
\hline Convenience Yield S & 0.013 & 0.000 & 0.013 & 0.000 & 0.013 & 0.000 \\
\hline \multirow[t]{2}{*}{ Convenience Yield C } & 0.013 & 0.000 & 0.013 & 0.000 & 0.014 & 0.000 \\
\hline & \multicolumn{6}{|c|}{ Quantities } \\
\hline Debt $\mathrm{S}$ & 0.535 & 0.083 & 0.589 & 0.089 & 0.625 & 0.095 \\
\hline Debt $\mathrm{C}$ & 1.031 & 0.055 & 0.942 & 0.055 & 0.850 & 0.055 \\
\hline Capital Share S & 0.329 & 0.049 & 0.358 & 0.051 & 0.381 & 0.055 \\
\hline Asset Value S & 0.571 & 0.090 & 0.629 & 0.096 & 0.667 & 0.103 \\
\hline Asset Value C & 1.163 & 0.082 & 1.128 & 0.087 & 1.082 & 0.092 \\
\hline Leverage S & 0.937 & 0.012 & 0.936 & 0.012 & 0.937 & 0.013 \\
\hline Leverage $\mathrm{C}$ & 0.888 & 0.020 & 0.837 & 0.020 & 0.787 & 0.019 \\
\hline \multirow[t]{2}{*}{ Early Liquidation Share } & 0.010 & 0.053 & 0.008 & 0.047 & 0.008 & 0.046 \\
\hline & \multicolumn{6}{|c|}{ Utility } \\
\hline Liquidity & 1.957 & 0.123 & 1.916 & 0.124 & 1.837 & 0.128 \\
\hline Consumption & 0.518 & 0.004 & 0.519 & 0.004 & 0.519 & 0.004 \\
\hline \multirow[t]{2}{*}{ Aggregate Welfare } & & & $1.17 \%$ & & $0.53 \%$ & \\
\hline & \multicolumn{6}{|c|}{ Bankruptcy Losses } \\
\hline DWL S & $0.02 \%$ & $0.06 \%$ & $0.02 \%$ & $0.06 \%$ & $0.02 \%$ & $0.07 \%$ \\
\hline DWL C & $0.10 \%$ & $0.09 \%$ & $0.01 \%$ & $0.01 \%$ & $0.00 \%$ & $0.00 \%$ \\
\hline Default Rate S & $0.25 \%$ & $0.09 \%$ & $0.25 \%$ & $0.08 \%$ & $0.25 \%$ & $0.09 \%$ \\
\hline Default Rate C & $0.22 \%$ & $0.21 \%$ & $0.02 \%$ & $0.03 \%$ & $0.00 \%$ & $0.00 \%$ \\
\hline
\end{tabular}

${ }^{a}$ : Deadweight losses are in units of the consumption good, multiplied by factor 100 .

${ }^{b}$ : Welfare is the percentage change of mean and volatility of the household value function relative to the benchmark model with $\theta=0.1$. 
optimal to make commercial banks completely safe.

Table 4: Different Capital Requirements at $\pi^{B}=15 \%$

\begin{tabular}{|c|c|c|c|c|c|c|}
\hline & \multicolumn{2}{|c|}{$10 \%$} & \multicolumn{2}{|c|}{$15 \%$} & \multicolumn{2}{|c|}{$20 \%$} \\
\hline & mean & stdev & mean & stdev & mean & stdev \\
\hline & \multicolumn{6}{|c|}{ Utility } \\
\hline Liquidity & 2.100 & 0.091 & 2.047 & 0.094 & 1.984 & 0.091 \\
\hline Consumption & 0.518 & 0.004 & 0.519 & 0.004 & 0.519 & 0.004 \\
\hline \multirow[t]{2}{*}{ Aggregate Welfare } & & & $0.077 \%$ & & $0.53 \%$ & \\
\hline & \multicolumn{6}{|c|}{ Bankruptcy Losses } \\
\hline DWL S & $0.017 \%$ & $0.073 \%$ & $0.018 \%$ & $0.076 \%$ & $0.015 \%$ & $0.069 \%$ \\
\hline DWL C & $0.109 \%$ & $0.093 \%$ & $0.011 \%$ & $0.011 \%$ & $0.001 \%$ & $0.001 \%$ \\
\hline Default Rate S & $0.114 \%$ & $0.042 \%$ & $0.115 \%$ & $0.042 \%$ & $0.114 \%$ & $0.042 \%$ \\
\hline Default Rate C & $0.253 \%$ & $0.217 \%$ & $0.027 \%$ & $0.028 \%$ & $0.002 \%$ & $0.002 \%$ \\
\hline
\end{tabular}

${ }^{a}$ : Deadweight losses are in units of the consumption good, multiplied by factor 100 .

${ }^{b}$ : Welfare is the percentage change of mean and volatility of the household value function relative to the benchmark model with $\theta=0.1$.

Lower Bailout Probability $\left(\pi^{B}=\mathbf{1 5 \%}\right)$ Shadow banks have more incentives to internalize the credit risk of their bonds when the bailout probability is lower. This leads to half the default rates of shadow banks compared with the benchmark calibration (see Table 4). The table further shows that the overall level of welfare is higher (more liquidity provision due to higher shadow banking liquidity quality at about the same level of consumption and less volatility) when shadow banks are safer. Since an increase in $\theta$ shifts intermediation activity towards shadow banks, the optimal capital requirement has to trade-off a reduction in deadweight losses due to commercial banks against an increase in deadweight losses due to shadow banks. If those banks have a lower failure rate and cause fewer bankruptcy losses, then for each dollar of intermediated assets shifted to shadow banks there is a greater reduction in deadweight losses. This provides more scope for ameliorating incentives for moral hazard in the commercial banking sector. The optimal capital requirement is in the interval 
between $15 \%$ and $20 \%$.

This exercise shows that the potential benefit from higher capital requirements depends on the response of non-regulated banks in the economy. In our calibration, reducing implicit bailout guarantees for shadow banks at the same time, turns out to increase the benefit of raising capital requirement.

Fair Deposit Insurance Fee \& Time Varying Capital Requirement Table 5 compares the benchmark economy to an environment with a time-varying insurance fee $\kappa_{t}$ and to an economy with a time-varying capital requirement.

We implement the fair deposit insurance fee experiment as follows: we set $\kappa$ each period such that in expectation all the bankruptcy losses from defaulting commercial banks can be fully covered. In a world without shadow banks, this would make commercial banks internalize their deadweight losses caused by their high leverage. However, the main effect of such a policy in our model is to shift intermediation activity to shadow banks. While both types of banks become slightly safer, i.e. lower default rates, the net effect is still a shift from the relatively safer sector to the relatively less safe sector. Similar to a higher capital requirement, the fair insurance fee reduces the size of the commercial banking sector. But unlike an increased capital requirement, the higher insurance fee does not limit the leverage of commercial banks. Therefore increasing $\kappa_{t}$ to its fair value leads to a welfare loss, as it produces a reduction in liquidity but no gain in consumption.

Our next experiment is a time varying capital requirement. That is, we set the capital requirement such that commercial banks' expected default rate is less than 25 basis points p.a. (6.25 bp per quarter). The resulting time varying capital requirement has a mean of $13 \%$, a standard deviation of $1 \%$ and co-varies strongly with the business cycle. Leverage and default rates of commercial banks becomes more counter-cyclical, while the overall level 
is lower, reducing financial fragility. When the capital requirement allows commercial banks to temporarily increase leverage during bad economic times they become more vulnerable to adverse economic shocks. This tends to increase the co-movements of default rates and deadweight losses from bankruptcy with bad states.

In contrast to the fair insurance premium case, intermediation activity of shadow banks does not pick up because the subsidized commercial banks can offer competitive rates. At the same time, an overall higher level of the capital requirement (13 percent compared to the 10 percent benchmark) requires commercial banks to lower their leverage. Altogether this means that the economy produces less liquidity. Moreover, since commercial bank deadweight-losses are more counter-cyclical, consumption becomes more procyclical, which risk-averse agents dislike. The reduction in liquidity and more pro-cyclical consumption leads to a substantial welfare loss compared to the benchmark case.

\section{Conclusion}

This paper proposes a novel model to study the consequences of higher bank capital requirements for the economy. The optimal level of capital regulation trades-off a reduction in liquidity services against an increase in the safety of the banking system and consumption. Increasing the capital requirement for regulated banks leads to more intermediation activity by the shadow banking system. Moreover, a higher capital requirement makes regulated banks safer, but it does not affect the riskiness of unregulated banks. Since a higher capital requirement shifts intermediated assets to unregulated banks, the net benefit of such a policy depends on baseline level of fragility of the unregulated banks. The qualitative finding that a higher capital requirement increases welfare is robust across our different policy experiments. However, our quantitative results highlight the role of additional policy measures that affect 
Table 5: Effect of Fair Insurance Fee \& Time Varying Capital Requirement

\begin{tabular}{|c|c|c|c|c|c|c|c|c|c|}
\hline & \multicolumn{3}{|c|}{ baseline } & \multicolumn{3}{|c|}{ fair kappa } & \multicolumn{3}{|c|}{ time varying theta } \\
\hline & \multicolumn{9}{|c|}{ Liquidity } \\
\hline$\Lambda^{S}$ & 0.808 & 0.058 & 0.547 & 0.822 & 0.054 & 0.537 & 0.811 & 0.057 & 0.520 \\
\hline Convenience Yield S & 0.013 & 0.000 & -0.267 & 0.012 & 0.001 & -0.492 & 0.013 & 0.000 & -0.265 \\
\hline \multirow[t]{2}{*}{ Convenience Yield C } & 0.013 & 0.000 & -0.490 & 0.013 & 0.000 & 0.304 & 0.013 & 0.000 & -0.249 \\
\hline & \multicolumn{9}{|c|}{ Quantities } \\
\hline Debt $\mathrm{S}$ & 0.535 & 0.083 & 0.154 & 0.646 & 0.156 & 0.131 & 0.571 & 0.096 & 0.148 \\
\hline Debt $\mathrm{C}$ & 1.031 & 0.055 & -0.097 & 0.888 & 0.122 & -0.120 & 0.981 & 0.074 & -0.119 \\
\hline Capital Share S & 0.329 & 0.049 & 0.148 & 0.416 & 0.093 & 0.129 & 0.346 & 0.056 & 0.143 \\
\hline Asset Value S & 0.571 & 0.090 & 0.210 & 0.726 & 0.170 & 0.167 & 0.608 & 0.103 & 0.198 \\
\hline Asset Value C & 1.163 & 0.082 & 0.005 & 1.017 & 0.157 & -0.067 & 1.147 & 0.095 & -0.021 \\
\hline Leverage $\mathrm{S}$ & 0.937 & 0.012 & -0.676 & 0.933 & 0.012 & -0.673 & 0.936 & 0.012 & -0.658 \\
\hline \multirow[t]{2}{*}{ Leverage C } & 0.888 & 0.020 & -0.245 & 0.883 & 0.020 & -0.259 & 0.861 & 0.013 & -0.488 \\
\hline & \multicolumn{9}{|c|}{ Utility } \\
\hline \multirow{3}{*}{$\begin{array}{l}\text { Liquidity } \\
\text { Consumption } \\
\text { Aggregate Welfare }\end{array}$} & 1.957 & 0.123 & 0.571 & 1.917 & 0.113 & 0.536 & 1.941 & 0.110 & 0.538 \\
\hline & 0.518 & 0.004 & 0.685 & $\begin{array}{c}0.518 \\
-0.77 \%\end{array}$ & 0.004 & 0.663 & $\begin{array}{c}0.519 \\
-5.18 \%\end{array}$ & 0.004 & 0.698 \\
\hline & \multicolumn{9}{|c|}{ Bankruptcy Losses } \\
\hline DWL S & $0.02 \%$ & $0.06 \%$ & -0.008 & $0.02 \%$ & $0.08 \%$ & 0.001 & $0.02 \%$ & $0.07 \%$ & 0.008 \\
\hline DWL C & $0.10 \%$ & $0.09 \%$ & -0.244 & $0.07 \%$ & $0.06 \%$ & -0.288 & $0.03 \%$ & $0.02 \%$ & -0.426 \\
\hline Default Rate S & $0.25 \%$ & $0.09 \%$ & -0.548 & $0.23 \%$ & $0.08 \%$ & -0.537 & $0.25 \%$ & $0.08 \%$ & -0.520 \\
\hline Default Rate C & $0.22 \%$ & $0.21 \%$ & -0.233 & $0.18 \%$ & $0.18 \%$ & -0.234 & $0.06 \%$ & $0.04 \%$ & -0.402 \\
\hline Time var. cap reqs & & & & & & & $13 \%$ & $1.03 \%$ & 0.572 \\
\hline
\end{tabular}

${ }^{a}$ : Deadweight losses are in units of the consumption good, multiplied by factor 100 .

${ }^{b}$ : Welfare is the percentage change of mean and volatility of the household value function relative to the benchmark model with $\theta=0.1$. 
unregulated banks such as implicit bailout guarantees. Our results further indicate that a higher deposit insurance fee does not make commercial banks safer. Rather, it shifts intermediation activity to the more fragile shadow banks without limiting leverage of commercial banks. Finally time-varying capital requirement successfully reduce financial fragility at the expense of lower liquidity provision. 


\section{References}

Acharya, V. V., P. Schnabl, and G. Suarez (2013): "Securitization without risk transfer," Journal of Financial economics, 107, 515-536.

Adrian, T. And A. B. Ashcraft (2012): "Shadow banking: a review of the literature," FRB of New York Staff Report.

Adrian, T. And N. Boyarchenko (2015): "Intermediary Leverage Cycles and Financial Stability," .

Adrian, T. AND H. S. Shin (2010): "Liquidity and leverage," Journal of financial intermediation, 19, 418-437.

Allen, F. And D. Gale (1994): "Limited market participation and volatility of asset prices," The American Economic Review, 933-955.

Begenau, J. (2015): "Capital Requirements, Risk Choice, and Liquidity Provision in a Business Cycle Model," Tech. rep., Harvard Business School.

Begenau, J., S. Bigio, And J. Majerovitz (2016): "What can we learn from the financial flows of the 2008-2009 crisis," Tech. rep., Working Paper.

Bernanke, B. S. (2005): "The global saving glut and the US current account deficit," Tech. rep.

Bigio, S. And J. Bianchi (2014): "Banks, Liquidity Management and Monetary Policy," Tech. rep.

Brunnermeier, M. K. And Y. Sannikov (2014): "A Macroeconomic Model with a Financial Sector," American Economic Review, 104, 379-421. 
Caballero, R. J. and A. Krishnamurthy (2009): "Global Imbalances and Financial Fragility," American Economic Review, 99, 584-88.

Chernenko, S. And A. Sunderam (2014): "Frictions in Shadow Banking: Evidence from the Lending Behavior of Money Market Mutual Funds," Review of Financial Studies, 27, $1717-1750$.

Christiano, L. And D. Ikeda (2013): "Leverage restrictions in a business cycle model," Tech. rep., National Bureau of Economic Research.

Christiano, L., R. Motto, and M. Rostagno (2010): "Financial Factors in economic Fluctuations," .

Corbae, D. and P. D'Erasmo (2014): "Capital requirements in a quantitative model of banking industry dynamics," .

Covitz, D., N. Liang, And G. A. Suarez (2013): "The Evolution of a Financial Crisis: Collapse of the Asset-Backed Commercial Paper Market," The Journal of Finance, 68, 815-848.

Diamond, D. W. And P. H. Dybvig (1983): "Bank Runs, Deposit Insurance, and Liquidity," Journal of Political Economy, 91, 401-419.

Diamond, D. W. and R. G. Rajan (2001): "Liquidity Risk, Liquidity Creation, and Financial Fragility: A Theory of Banking," Journal of Political Economy, 109, 287-327.

Donaldson, J., G. Piacentino, and A. Thakor (2015): "Warehouse banking," WP, Washington University in St. Louis, WP.

Elenev, V., T. Landvoigt, and S. Van Nieuwerburgh (2015): "Phasing out the GSEs," . 
Feenstra, R. C. (1986): "Functional Equivalence between Liquidity Costs and the Utility of Money," Journal of Monetary Economics, 17, 271-291.

Flannery, M. J. And S. M. Sorescu (1996): "Evidence of bank market discipline in subordinated debenture yields: 1983-1991," The Journal of Finance, 51, 1347-1377.

Freixas, X. And J.-C. Rochet (1998): Microeconomics of Banking, MIT Press, Cambridge, Massachusetts.

Gallin, J. (2013): "Shadow banking and the funding of the nonfinancial sector," Tech. rep., Federal Reserve Bank.

Gandhi, P. And H. Lustig (2013): "Size anomalies in US bank stock returns," The Journal of Finance.

Garleanu, N. And L. H. Pedersen (2011): "Margin-based asset pricing and deviations from the law of one price," Review of Financial Studies, 24, 1980-2022.

Gennaioli, N., A. Shleifer, And R. W. Vishny (2013): "A model of shadow banking," The Journal of Finance, 68, 1331-1363.

Gertler, M. And P. Karadi (2011): "A model of unconventional monetary policy," Journal of monetary Economics, 58, 17-34.

Gertler, M. And N. Kiyotaki (2010): "Financial intermediation and credit policy in business cycle analysis," Handbook of monetary economics, 3, 547-599.

Gertler, M., N. Kiyotaki, And A. Prestipino (2016): "Wholesale Banking and Bank Runs in Macroeconomic Modelling of Financial Crises," Tech. rep., National Bureau of Economic Research. 
Gomes, J., U. Jermann, And L. Schmid (2014): "Sticky leverage," .

Goodhart, C. A., A. K. Kashyap, D. P. Tsomocos, and A. P. Vardoulakis (2012): "Financial regulation in general equilibrium," Tech. rep., National Bureau of Economic Research.

Gorton, G., S. Lewellen, and A. Metrick (2012): "The Safe-Asset Share," The American Economic Review, 102, 101-106.

Gorton, G. AND A. Metrick (2012): "Securitized banking and the run on repo," Journal of Financial Economics, 104, 425 - 451, market Institutions, Financial Market Risks and Financial Crisis.

Gorton, G. And G. Pennacchi (1990): "Financial Intermediaries and Liqduity Creation," The Journal of Finance, 45, 49-71.

Gu, C., F. Mattesini, C. Monnet, and R. Wright (2013): "Banking: A new monetarist approach," The Review of Economic Studies, 80, 636-662.

Hanson, S. G., A. Shleifer, J. Stein, And R. W. Vishny (2014): "Banks as Patient Fixed-Income Investors," Tech. rep., NBER Working Paper No. 20288.

Harris, M., C. C. Opp, And M. M. Opp (2015): "Macroprudential Bank Capital Regulation in a Competitive Financial System," .

He, Z., B. T. Kelly, and A. Manela (2015): "Intermediary Asset Pricing: New Evidence from Many Asset Classes," Available at SSRN 2662182.

He, Z. and A. Krishnamurthy (2013): "Intermediary Asset Pricing," American Economic Review, 103, 732-770. 
HuAng, J. (2015): "Banking and Shadow Banking," Tech. rep.

Krishnamurthy, A. And A. Vissing-Jorgensen (2012): "The aggregate demand for treasury debt," Journal of Political Economy, 120, 233-267.

_ (2013): "Short-term debt and financial crises: What we can learn from US Treasury supply," unpublished, Northwestern University, May.

Lucas, R. E. J. And J. P. Nicolini (2014): "On the Stability of Money Demand," Journal of Monetary Economics.

Meeks, R., B. Nelson, And P. Alessandri (2013): "Shadow banks and macroeconomic instability," Bank of Italy Temi di Discussione (Working Paper) No, 939.

Moreira, A. And A. Savov (2014): "The macroeconomics of shadow banking," Tech. rep., National Bureau of Economic Research.

Nguyen, T. T. (2014): "Bank Capital Requirements: A Quantitative Analysis," Tech. rep., Carnegie-Rochester Conference Series on Public Policy, Forthcoming.

Plantin, G. (2014): "Shadow banking and bank capital regulation," Review of Financial Studies.

Poterba, J. M. and J. J. Rotemberg (1986): "Money in the Utility Function: An Empirical Implementation," .

Pozsar, Z. (2013): "Institutional cash pools and the Triffin dilemma of the US banking system," Financial Markets, Institutions \& Instruments, 22, 283-318.

Pozsar, Z., T. Adrian, A. Ashcraft, And H. Boesky (2012): "Shadow Banking," Tech. rep., Federal Reserve Bank of New York. 
Sidrauski, M. (1967): "Inflation and Economic Growth," Journal of Political Economy, $75,796-810$.

Sunderam, A. (2014): "Money creation and the shadow banking system," Review of Financial Studies. 
dummy comment inserted by tex2lyx to ensure that this paragraph is not empty

\section{A Appendix}

\section{A.1 Dynamic Model}

\section{A.1.1 FOC for $b_{t}^{S}$}

Rewrite $\mathcal{F}^{S}\left(L_{t}^{S}\right)$ as

$$
\begin{aligned}
\mathcal{F}^{S}\left(L_{t}^{S}\right) & =\left(1-F_{t}^{S}\right)\left(\rho_{t}^{S,+}\left(1-\ell_{t}\left(1-x_{t}\right)\right)-L_{t}^{S}\right)-F_{t}^{S} \delta_{S} \\
& =\left(1-\ell_{t}\left(1-x_{t}\right)\right) \int_{\frac{L_{t}^{S}-\delta_{S}}{1-\ell_{t}\left(1-x_{t}\right)}} \rho d F(\rho)-\left(1-F_{t}^{S}\right) L_{t}^{S}-F_{t}^{S} \delta_{S}
\end{aligned}
$$

Further compute

$$
\frac{\partial\left(1-\ell_{t}\left(1-x_{t}\right)\right)}{\partial L_{t}^{S}}=-\varrho_{t}^{S} \frac{1-x_{t}}{x_{t}}=-\ell_{t} \frac{1-x_{t}}{L_{t}^{S}} .
$$

and define

$$
\mathcal{L}_{t}^{S}\left(L_{t}^{S}\right)=\frac{\partial}{\partial L_{t}^{S}} \frac{L_{t}^{S}-\delta_{S}}{1-\ell_{t}\left(1-x_{t}\right)}=\frac{1-\delta_{S} \varrho_{t}^{S} \frac{1-x_{t}}{x_{t}}}{\left(1-\ell_{t}\left(1-x_{t}\right)\right)^{2}}=\frac{1-\delta_{S} \ell_{t} \frac{1-x_{t}}{L_{t}^{S}}}{\left(1-\ell_{t}\left(1-x_{t}\right)\right)^{2}}
$$

Now we can calculate

$$
\begin{aligned}
\frac{\mathcal{F}^{S}\left(L_{t}^{S}\right)}{\partial L_{t}^{S}} & =-\ell_{t} \frac{1-x_{t}}{L_{t}^{S}}\left(1-F_{t}^{S}\right) \rho_{t}^{S,+}-f_{t}^{S} \mathcal{L}_{t}^{S}\left(L_{t}^{S}\right)\left(L_{t}^{S}-\delta_{S}\right)-\left(1-F_{t}^{S}\right)+f_{t}^{S} \mathcal{L}_{t}^{S}\left(L_{t}^{S}\right) L_{t}^{S}-f_{t}^{S} \mathcal{L}_{t}^{S}\left(L_{t}^{S}\right) \delta_{S} \\
& =-\left(1-F_{t}^{S}\right)\left(1+\ell_{t}\left(1-x_{t}\right) \frac{\rho_{t}^{S,+}}{L_{t}^{S}}\right)
\end{aligned}
$$

Therefore the FOC for $b_{t}^{S}$ is

$$
q_{t}^{S}=-b_{t}^{S} q^{\prime}\left(b_{t}^{S}\right)+\mathrm{E}_{t}\left[M_{t+1}\left(1-F_{t}^{S}\right)\left(1+\ell_{t}\left(1-x_{t}\right) \frac{\rho_{t}^{S,+}}{L_{t}^{S}}\right)\right] .
$$




\section{A.1.2 Derivation of $\left(q^{S}\right)^{\prime}\left(b_{t}^{S}\right)$}

Recall the definition of the recovery value for S-banks as

$$
r^{S}\left(L_{t}^{S}\right)=\left(1-\xi^{S}\right) \frac{\rho_{t}^{S,-}\left(1-\ell_{t}\left(1-x_{t}\right)\right)}{L_{t}^{S}},
$$

with the conditional expectation

$$
\rho_{t}^{S,-}=\mathrm{E}_{\rho, S}\left[\rho \mid \rho<\frac{L_{t}^{S}-\delta_{S}}{1-\ell_{t}\left(1-x_{t}\right)}\right] .
$$

First compute

$$
\frac{\partial}{\partial L_{t}^{S}} \frac{1-\ell_{t}\left(1-x_{t}\right)}{L_{t}^{S}}=\frac{-\varrho_{t}^{S} \frac{1-x_{t}}{x_{t}} L_{t}^{S}-\left(1-\ell_{t}\left(1-x_{t}\right)\right)}{\left(L_{t}^{S}\right)^{2}}=-\frac{1}{\left(L_{t}^{S}\right)^{2}} .
$$

We can rewrite the recovery value times the probability of default as

$$
F_{t}^{S} r_{t}^{S}=\frac{\left(1-\xi_{S}\right)\left(1-\ell_{t}\left(1-x_{t}\right)\right)}{L_{t}^{S}} \int_{-\infty}^{\frac{L_{t}^{S}-\delta_{S}}{1-\ell_{t}\left(1-x_{t}\right)}} \rho d F_{\rho, S}(\rho) .
$$

Differentiating this expression with respect to $b_{t}^{S}$ gives

$$
\begin{aligned}
\frac{\partial F_{t}^{S} r_{t}^{S}}{L_{t}^{S}}= & -\frac{\left(1-\xi_{S}\right)}{\left(L_{t}^{S}\right)^{2}} F_{t}^{S} \rho_{t}^{S,-}+\frac{f_{t}^{S}}{L_{t}^{S}}\left(1-\xi_{S}\right) \mathcal{L}_{t}^{S}\left(L_{t}^{S}\right)\left(L_{t}^{S}-\delta\right) \\
& =-\frac{F_{t}^{S} r_{t}^{S}}{L_{t}^{S}\left(1-\ell_{t}\left(1-x_{t}\right)\right)}-\frac{f_{t}^{S}}{b_{t}^{S}} \mathcal{L}_{t}^{S}\left(L_{t}^{S}\right)\left(1-\xi_{S}\right)\left(\delta-L_{t}^{S}\right) .
\end{aligned}
$$

Using $L_{t}^{S}=b_{t}^{S} /\left(Z_{t}+p_{t}\right)$, the complete derivative of the household's bond pricing equation for $q^{S}$ (16) with respect to $b_{t+1}^{S}$ is therefore

$$
\frac{\partial q^{S}\left(b_{t+1}^{S}\right)}{\partial b_{t+1}^{S}}=-\mathrm{E}_{t}\left\{\left(1-\pi_{B}\right) M_{t, t+1}\left[\frac{F_{t+1}^{S} r_{t+1}^{S}}{b_{t+1}^{S}\left(1-\ell_{t+1}\left(1-x_{t+1}\right)\right)}+\frac{f_{t+1}^{S}}{b_{t+1}^{S}} \mathcal{L}^{S}\left(L_{t+1}^{S}\right)\left(\left(1-\xi_{S}\right) \delta_{S}+\xi_{S} L_{t+1}^{S}\right)\right]\right\}
$$

\section{A.1.3 Gamma Distribution}

The gamma cdf is $\Gamma\left(\rho ; \chi_{0}, \chi_{1}\right)$ with parameters $\left(\chi_{0}, \chi_{1}\right)$. The parameters map into mean and variance of the distribution as

$$
\begin{aligned}
& \chi_{1}=\sigma_{\rho}^{2} / \mu_{\rho} \\
& \chi_{0}=\mu_{\rho} / \chi_{1} .
\end{aligned}
$$


Denote the pdf as $\gamma\left(\rho ; \chi_{0}, \chi_{1}\right)$.

It is a standard result is statistics that the conditional expectations are

$$
\begin{aligned}
& \mathrm{E}(\rho \mid \rho<x)=\mu_{\rho} \frac{\Gamma\left(x ; \chi_{0}+1, \chi_{1}\right)}{\Gamma\left(x ; \chi_{0}, \chi_{1}\right)} \\
& \mathrm{E}(\rho \mid \rho>x)=\mu_{\rho} \frac{1-\Gamma\left(x ; \chi_{0}+1, \chi_{1}\right)}{1-\Gamma\left(x ; \chi_{0}, \chi_{1}\right)} .
\end{aligned}
$$

This means the expressions for payoffs and recovery values are

$$
\begin{gathered}
F_{\rho}^{j} \rho^{j,-}=\mu_{\rho} \Gamma\left(\frac{L_{t}^{j}-\delta_{j}}{1-\ell_{t}^{j}\left(1-x_{t}\right)} ; \chi_{0}+1, \chi_{1}\right), \\
\left(1-F_{\rho}^{j}\right) \rho^{j,+}=\mu_{\rho}\left(1-\Gamma\left(\frac{L_{t}^{j}-\delta_{S}}{1-\ell_{t}^{j}\left(1-x_{t}\right)} ; \chi_{0}+1, \chi_{1}\right)\right) .
\end{gathered}
$$

